\title{
Drawing Comparisons: Cellini's Perseus Liberating Andromeda and the Paragone Debate
}

\section{Gwendolyn Trottein}

Volume 34, numéro 2, 2009

URI : https://id.erudit.org/iderudit/1069489ar

DOI : https://doi.org/10.7202/1069489ar

\section{Aller au sommaire du numéro}

\section{Éditeur(s)}

UAAC-AAUC (University Art Association of Canada | Association d'art des universités du Canada)

\section{ISSN}

0315-9906 (imprimé)

1918-4778 (numérique)

\section{Découvrir la revue}

\section{Citer cet article}

Trottein, G. (2009). Drawing Comparisons: Cellini's Perseus Liberating Andromeda and the Paragone Debate. RACAR : Revue d'art canadienne / Canadian Art Review, 34(2), 55-73. https://doi.org/10.7202/1069489ar

\section{Résumé de l'article}

L'analyse porte sur Persée libérant Andromède, relief en bronze qui fait partie intégrante de l'ensemble sculpté entre 1545 et 1554 par Benvenuto Cellini pour la Loggia dei Lanzi de Florence. Ce relief, rajouté à la fin du projet, offre la clef de la signification théorique et polémique du colossal Persée monté sur son piédestal orné de figures. En bas du monument, encadrée de marbre comme un tableau, la Libération d'Andromède fait ainsi entrer le spectateur avisé dans la querelle de l'époque sur la valeur respective des arts, le fameux débat du paragone, mais elle ne se borne pas à une simple évocation de ce débat, et elle n'affirme pas seulement l'infériorité de la peinture par rapport à la sculpture. Le nu mystérieux et sans profondeur du centre du relief fonctionne en tant qu'agent provocateur pour lancer une comparaison entre la sculpture en relief, qui ressemble à du dessin, et une autre sculpture plus en profondeur comme celle d'Andromède à ses côtés. Cette comparaison peu flatteuse pour les arts bidimensionnels concerne aussi l'architecture, comprise par Cellini comme un art de la surface apparenté au dessin et à la perspective. Pour

l'orfèvre-sculpteur qu'est Cellini, la preuve à la fois de la bonne peinture et de la bonne sculpture réside dans leur capacité à libérer la beauté plastique et humaine des contraintes de la surface. Enchaînée au mur littéralement et figurativement, son Andromède en relief illustre certes le plus haut degré de la peinture, mais en même temps l'impuissance et les limites de cet art féminin. Sì l'autobiographie et les écrits théoriques de Cellini donnent bien à la sculpture en ronde bosse la première place parmi les arts, encore fallait-il prouver sans recours aux mots, donc à un autre art, cette supériorité : c'est ce que fait voir, et de façon systématique, le monument du Persée, à condition d'en considérer l'ensemble.
Tous droits réservés @ UAAC-AAUC (University Art Association of Canada | Association d'art des universités du Canada), 2009
Ce document est protégé par la loi sur le droit d'auteur. L'utilisation des services d'Érudit (y compris la reproduction) est assujettie à sa politique d'utilisation que vous pouvez consulter en ligne.

https://apropos.erudit.org/fr/usagers/politique-dutilisation/ 


\title{
Drawing Comparisons: Cellini's Perseus Liberating Andromeda and the Paragone Debate
}

\author{
Gwendolyn Trottein, Bishop's University
}

\begin{abstract}
Résumé
L'analyse porte sur Persée libèront Andromède, relief en bronze qui fait partie intégrante de l'ensemble sculpté entre 1545 et 1554 par Benvenuto Cellini pour la Loggia dei Lanzi de Florence. Ce relief, rajouté à la fin du projet, offre la clef de la signification théorique et polémique du colossal Persée monté sur son piédestal orné de figures. En bas du monument, encadrée de marbre comme un tableau, la Libération d'Andromède fait ainsi entrer le spectateur avisé dans la querelle de l'époque sur la valeur respective des arts, le fameux débat du paragone, mais elle ne se borne pas à une sımple évocation de ce débat, et elle n'affirme pas seulement l'infériorité de la peinture par rapport à la sculpture. Le nu mystérieux et sans profondeur du centre du relief fonctionne en tant qu'agent provocateur pour lancer une comparaison entre la sculpture en relief, qui ressemble à du dessin, et une autre sculpture plus en profondeur comme celle d'Andromède à ses côtés. Cette comparaison peu flatteuse pour les arts bıdimensionnels concerne aussi l'architecture, comprise par Cellini comme un art de la surface apparenté au dessin et à la perspective. Pour l'orfèvre-sculpteur qu'est Cellini, la preuve à la fois de la bonne peinture et de la bonne sculpture réside dans leur capacité à libérer la beauté plastıque et humaine des contraintes de la surface. Enchaînée au mur littéralement et figurativement, son Andromède en relief illustre certes le plus haut degré de la peinture, mais en même temps l'impuissance et les limites de cet art féminin. Sı l'autobiographie et les écrits théorıques de Cellini donnent bien à la sculpture en ronde bosse la première place parmi les arts, encore fallait-il prouver sans recours aux mots, donc à un autre art. cette supériorité: c'est ce que fait voir, et de façon systématique, le monument du Persée, à condition d'en considérer l'ensemble.
\end{abstract}

$\mathrm{T}$ bronze bas-relief (fig. 1) that formed part of Benvenuto Cellini's Perseus and Medusa, the sculptural ensemble that has occupied the east arcade of the Loggia dei Lanzi in Florence's Piazza della Signoria since it was unveiled in 1554 (fig. 2). ${ }^{1}$ Our aim is to assess the ways in which the relief, as a gloss representing art forms other than sculpture, can be seen to impact, enhance, and alter the art-theoretical content of Cellini's Perseus and Medusa as a whole.

The depiction of Perseus Liberating Andromeda was Cellini's final contribution to his public masterwork and may be considered the finishing touch to a monumental statuary group supported by an elaborate base or pedestal. The relief was not cast until 1552, whereas Medusa and the colossal Perseus were cast in June of 1548 and during the winter of 1549, respectively. ${ }^{2}$ Although Perseus and Medusa's white marble base was designed but not actually carved by Cellini, the smaller bronze statues in its four niches are entirely his work, and date to April of 1552 ; that is, they are believed to have preceded the relief (fig. 3). ${ }^{3}$ The curious bronze relief does not seem to have figured in the early plans for the monument, nor does Cellini discuss it in any detail in his autobiographical writings.

Descriptions of the Perseus and Medusa on its marble base, including that of Giorgio Vasari in the 1568 edition of the Lives, often also omit to mention Cellini's Perseus Liberating Andromeda. ${ }^{4}$ Photographs, old and more recent, usually exclude it. ${ }^{5}$ And perhaps such an omission is justified, because the work in relief appended to the Loggia's parapet beneath the pedestal seems an unnecessary footnote to a sufficiently embellished and claborate ensemble. Moreover, the visually expendable rclicf constitutes a radical departure from the type of art that towers above it, for the 90 by $81 \mathrm{~cm}$ bronze panel is framed in marble as though it were a painting, and, like poetry, it relates a story unfolding in time. No such sustained narrative intention has been discerned in the mythological figures of the Perseus and Medusa.

Like an open book, the relief's narrative splits down the middle into different pages, which, despite the semblance of unity, refer to two chronologically distinct but contiguous (Ovidian passages. First, on the left-hand side, Perseus plunges earthward to save Andromeda from the monster as, on the facing side, the anger of her fiancé and his men gathers momentum, heralding the battle to come. The relief's later date, bookish character, and differing form (relief) and genre (narrative) suggest that it functions as a commentary or gloss on the Perseus, one analogous to that afforded by Cellini's autobiography, the Vita (1558-66) or his treatises on the arts, the Trattati (1565-67). The expansion of Cellini's artistic practice into the literary domains of narration and art theory is symptomatic of the phase of his career following the completion of his major work of sculpture, the Perseus and Medusa. ${ }^{6}$

Visible accomplishment followed by verbal explanation is a leitmotif of Cellini's writings about his art. His five-hundred folio autobiography contains several instances of the artist first allowing his jewellery and sculpture to speak for itself, to make an aesthetic impact before it is glossed for admiring patrons. ${ }^{7}$ Narration, explication, and evaluation of one's life and work is subsequent to actual achievement and ought not to be necessary; states Cellini about the writing of his autobiography: "It is true enough that men who have worked hard and shown a touch of genius have already proved their worth to the world. They have shown that they are capable men and they are famous, and perhaps that should be sufficient." 8 If the relief-like 


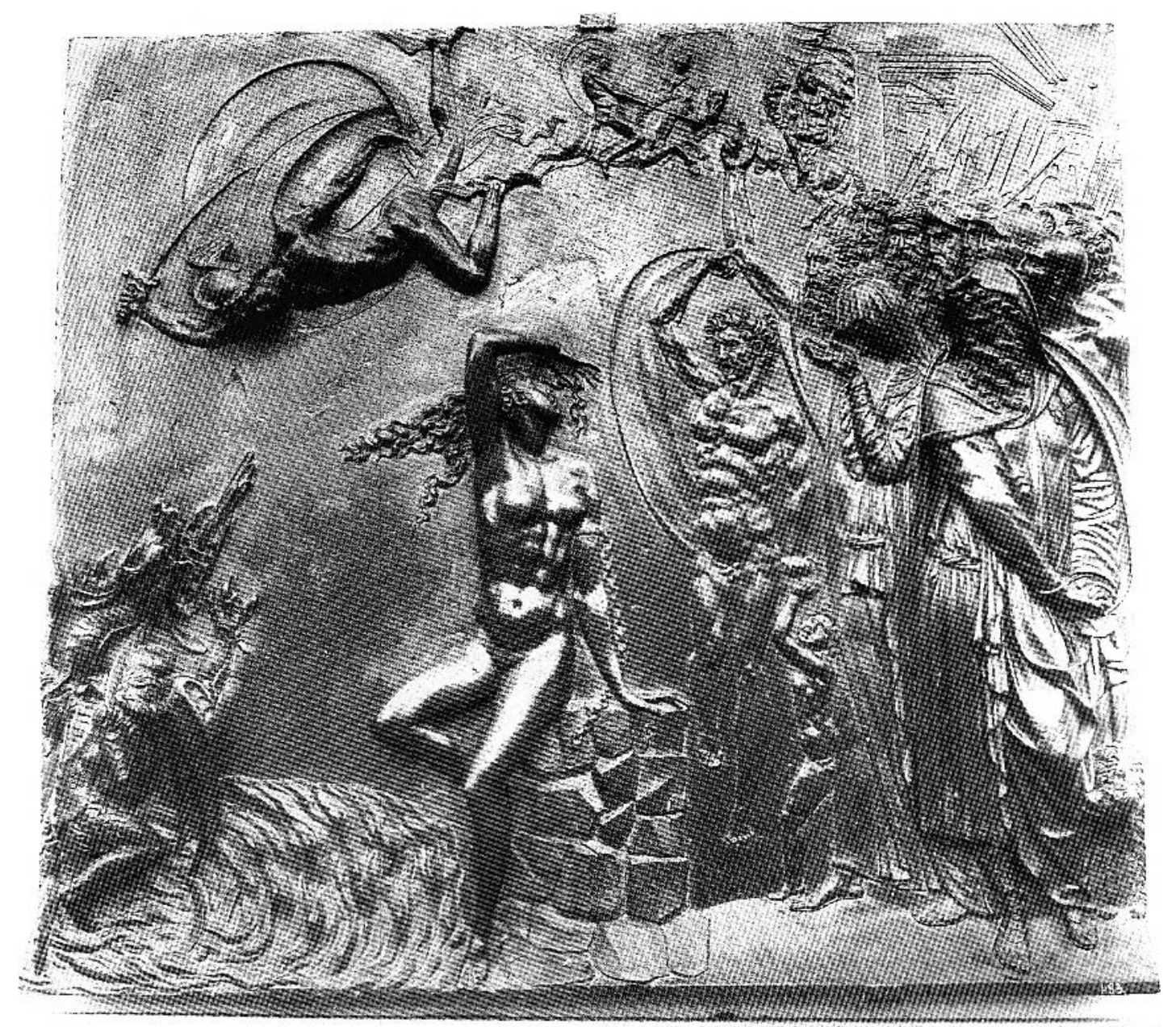

Figure I. Benvenuto Cellini, Perseus Liberating Andromeda, 1552. Bronze relief. $90 \times 81 \mathrm{~cm}$. Bargello Museum, Florence (Photograph by David Finn).

Cellini's autobiography-comments and promotes however reluctantly the works that preceded it, how then is this bronze "text" to be read? What did it communicate about the artist's deeds, the sculptures above it, whose worth and fame had already been proven?

Asking and answering these questions represents a task different from that of examining the iconographic treatment of the Ovidian myth pictured in the relief in the terms set out in 1939 by Erwin Panofsky in his famous methodological schema. ' Instead of matching Renaissance literary themes to likely counterparts in the visual arts, the present study explores the theoretical and functional relationships among three units of an individual goldsmith-sculptor's singular work of art. Accordingly, texts written by Cellini rather than external sources are privileged as supporting documents. And because the present essay's aim is to determine how an artist theorizes his artistic creation non-verbally, one might say sculpturally, through the addition of a very specific element to a complex ensemble, considerable emphasis is placed on the analytical gaze of the viewer and on purely visual aspects of Cellini's ensemble in its setting. At stake is the intrinsic coherence and auto-sufficiency of Cellini's Perseus and Medusa, an aesthctic object so resolutely self-reliant that it supplies the standards by which it is to be judged.

Rather than denying the existence of more traditional and textual iconographic content, such as the relief's commemoration of the reign of Cosimo de' Medici symbolized by Perseus (the Medici prince) rescuing Andromeda (Florence), our approach to Cellini's Perseus Liberating Andromeda postulates multiple layers of meaning. ${ }^{10}$ However, in terms of effective Medici propaganda, neither the Perseus on its base nor the relief has ever functioned very satisfactorily, as several commen- 




I Igure 2. Benvenuto Cellini, Perseus and Medusa, 1545 54, view of the ensemble. Bronze and marble. Loggia dei L_anzı. Florence (Photograph by David Finn).

tators have pointed out." John Shearman decmed the work's general opacity of content to be an attribute of a mannerist or aestheticizing style, disdainful of political or literary meaning. As a consequence of this position, Shearman's classic Mannerism and his later essays stopped short of analyzing in detail symbolic elements of the relief or the ensemble. ${ }^{12}$ Michacl Cole's Cellini and the Principles of Sculpture has the considerable merit of being the first study to tackle Perseus Liberating Andromeda as both richly signifying and as art about art. Drawing predominantly upon Aristotle, Cole reads the relief as an allegory of the processes of an art of sculpture whose aim is virtue. Central to his interpretation is the designation of the naked man who runs toward the spectator shouting and gesticulating as fury, a divine or demonic poetic frenzy 13 (fig. 4).

The running figure has long been the stumbling block for a traditional iconographic interpretation because, although the

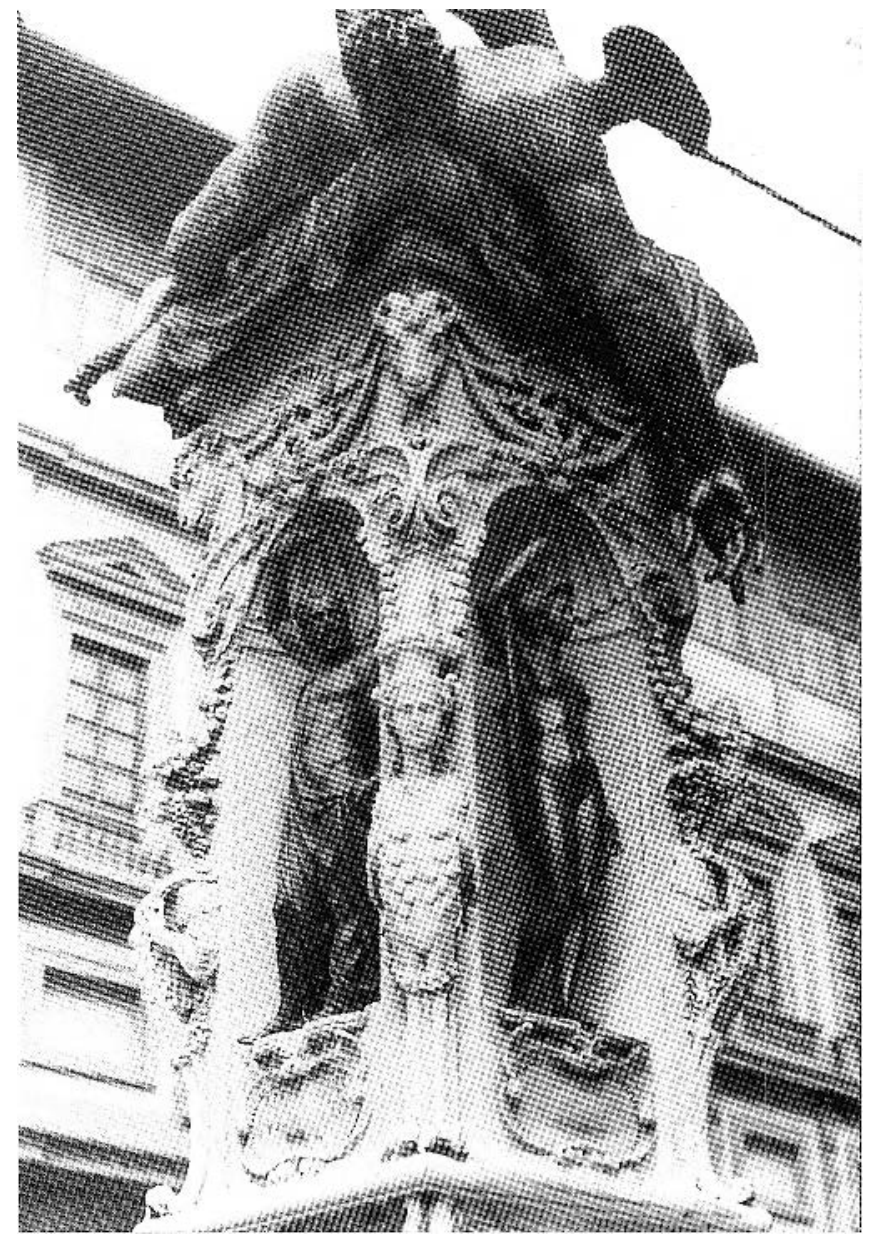

Figure 3. Benvenuto Cellıni, base of Perseus and Medusa. 1545 -54. view with Jupiter and Minerva. Marble and bronze. $199 \mathrm{~cm}$. Now in the Bargello Museum. Florence (Photograph by David Finn).

mythological Greek hero Perseus, the sacrificed heroine Andromeda, and Andromeda's grieving parents can be identified easily, no consensus has been reached concerning his identity. He has been labelled variously as Andromeda's jealous uncle Phineus, as a Medici forefather (hence the child holding his hand), as a second Perseus, and even as an alter ego of the artist. If, instead of hastening to put a name or abstract label to this figure-a relatively minor actor of Cellini's complicated sculptural ensemble in the piazza-it is considercd as a locus of iconological tension akin to Aby Warburg's nymph, ${ }^{14}$ the previously puzzling detail unlocks a system of formal expression. The mute discourse launched visually by the nameless male nude turns out to be less a philosophical exposition on the mental and technical processes of making art than a polcmical demonstration of the superiority of the art of sculpture. In other words, the addition of the relief causes the ensemble to function 




Figure 4. Benvenuto Cellini, Perseus Liberating Andromeda, 1552, detail with running figure. Bronze relief, $90 \times 81 \mathrm{~cm}$. Bargello Museum. Florence (Photograph by David Finn). effectively as a polemical contribution to the paragone (comparison) debate. 15

The controversy surrounding the ranking and relative importance of the different arts was lively at mid-century when Cellini returned to Florence, and would become again quite bitter at the time of Michelangelo's funeral in 1564.16 Alessandro Nova has demonstrated that several sixteenth-century fresco cycles participate as gemahlte Theorie (painted theory) in the paragone debate and has suggested that Cellini's marble Narcissus refers to it as well. ${ }^{17}$ Consequently, there is ample cause to consider the ensemble of Cellini's work for the piazza as "sculpted theory." The question for the sculptor then becomes how to defend his own art without recourse to another art form and the implicit recognition of its authority. How can forms be made to speak without the superimposition or substitution of language as a superior conceptual vehicle? What exactly is Cellini's nude male silently shouting as he rushes headlong toward confrontation with the viewer of the relief?

\section{Sculpture and Drawing}

Although the running man's uncertain identity, inappropriate nudity, and display of excessive emotion have tended to capture the attention of commentators, the manner in which the figure is sculpted is perhaps its most meaningful aspect. 18 One art historian, Charles Avery, has observed that the naked figure "is scarcely in relief at all" and that its treatment is "deliberately, almost perversely, anti-spatial." 19 For Avery, Cellini's running man illustrates the draughtsmanly characteristics of a type of Renaissance relief sculpture whose initial form was obtained

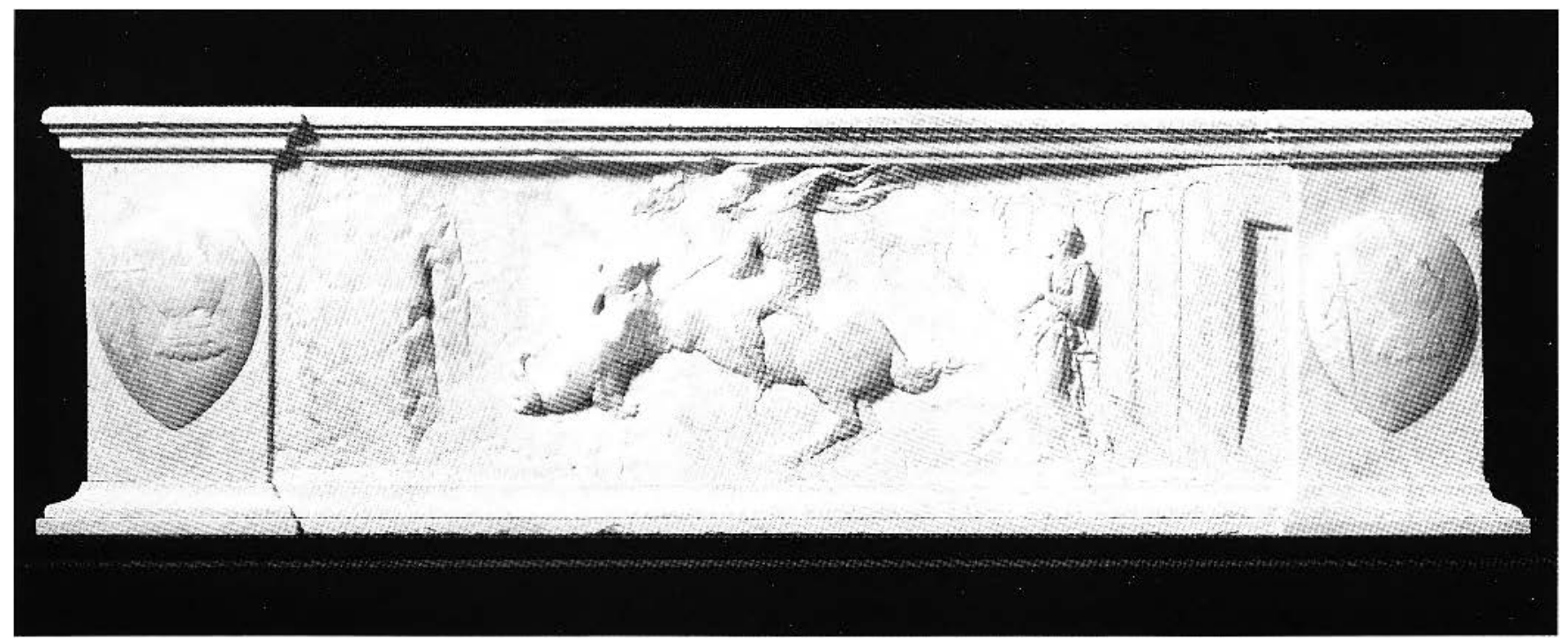

Figure 5. Donatello, Saint George and the Drogon. ca. 1417. Marble relief, $39 \times 120 \mathrm{~cm}$. Bargello Museum. Florence (Credit: Scala/Art Resource). 
by cutting into a wax surface with a sharp implement. He cites Donatello and Baccio Bandinelli as other Florentine sculptors who favoured this type of "drawing" in wax.

The shallow relief, graphic quality, and sketchiness of Cellini's figure evokes thus the work of two other Renaissance sculptors, Donatello and Bandinelli, both associated in different ways with the art of drawing and connected to Cellini's competitive efforts on the piazza. ${ }^{20}$ Cellini affirms that Perseus and Medusa was intended to be compared to, and to rival in a worthy way (degnamente a paragone), Donatello's Judith and Holofernes, which resided at that time at the other end of the Loggia. ${ }^{21}$ Donatello, praised by Cellini as a "true painter,"22 was known for his flattened rclicf, or rilievo schiacciato, and he had used bronze bas-reliefs to decorate the triangular base of his Judith and Holofernes. Since Cellini's base contained no sculptural relief executed by his own hand, the addition of a relief in bronze to the parapet under the base of the Perseus created an additional point of comparison between the sculpture of the fifteenth-century Florentine master and Cellini's sixteenth-century work. More pointedly, the running figure at its center challenged the earlier sculptor in kind by mimicking the graphic and pictorial qualities of relief sculpture seen for example in Donatello's $S t$. George and the Dragon for Orsanmichele (fig. 5). Furthermore the adjunction of the Andromeda relief with its "sketched" figures allowed Cellini to import art forms other than relief sculpture per se into the statement made by his Perseus in the paragone debate.

If Donatello was a draughtsman in stone and metal, Bandinelli prided himself for his drawing on paper. Bandinelli, whose father had been a goldsmith, staked his claim to be the foremost sculptor in Florence on his talents as draughtsman and favoured instruction based on the graphic arts. ${ }^{23}$ His autobiography, the Memoriale, makes explicit his preference for drawing, writing, and even painting over the art of sculpture. ${ }^{24} \mathrm{~A}$ self-portrait painted in the 1530s and now in the Isabella Stuart Gardner Museum in Boston ${ }^{25}$ shows the sculptor dressed as a nobleman and holding a preparatory sketch for his larger than lifc marble Hercules and Cacus, which had stood opposite Michelangelo's David at the entrance to the ducal palace since 1534 (fig. 6). Although Vasari's otherwise highly critical biography of Bandinelli concedes the cavaliere a merited fame in drawing, Cellini's Vita is not so generous; it caricatures Bandinelli as disegno-obsessed. 26 When the abundant defects of his Hercules and Cacus are enumerated by Cellini before the duke, Bandinelli can only cry out, "Oh, you wicked slanderer, what about my disegno?"27 Cellini then dismisses Bandinelli's disegno summarily-in terms of both draughtsmanship and project or design - with the depreciatory reply that anyone good at disegno would never make a bad statue, and therefore Bandinelli's disegno must be of the same quality as his marble Hercules.

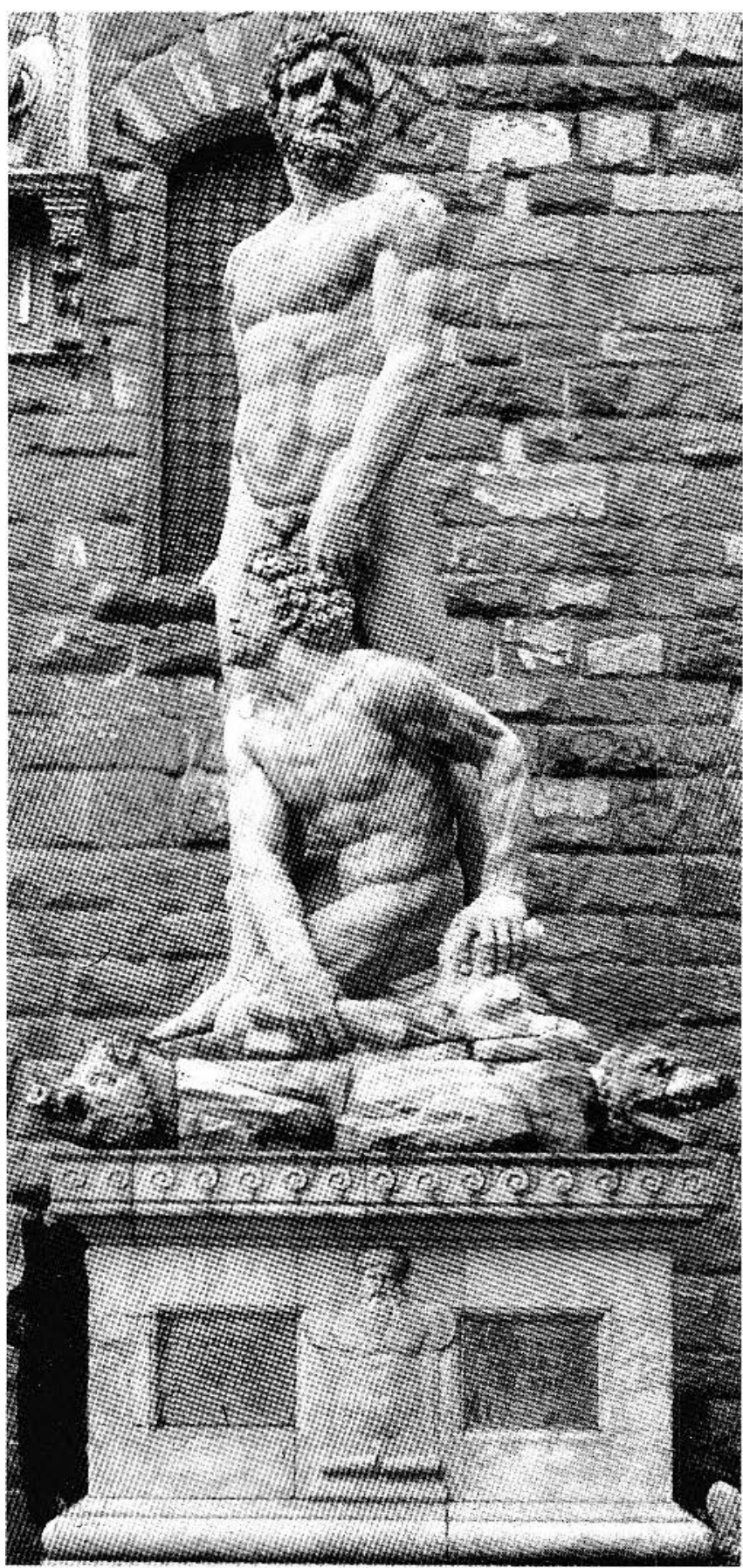

Figure 6. Baccio Bandinelli, Hercules and Cocus, 1534, detail with turbaned herms of the base. Marble. Piazza della Signoria, Florence (Photo: author).

Arguably the most pleasing element of Bandinelli's statue group in the piazza is not its blocky statues in the round, but rather the ingenious grotesques carved in bas-relief on its large cubic base (fig. 6). Nor does the autobiographical Cellini mock these four bearded and turbaned herms, whose flattened torsos 
resemble parchment curling at the bottom edges like posters peeling from a wall. Bandinelli excelled in this draughtsmanly type of sculpture of the planar surface, and Cellini's deeply carved base containing fully rounded statues in bronze in deep niches does not seek to rival his predecessor's base in this field of endeavour. And yet, during the years 1549-63, Cellini competed with Bandinelli for relief commissions, first for a part of the reliefs to decorate the choir of Santa Maria del Fiore already begun by Bandinelli, then for bronze reliefs for the pulpit or the doors of the cathedral. Neither man wished the orher as an equal partner on these projects, as a letter written by Bandinclli to the duke of Florence makes clear: the older artist complains that even as small as Cellini's figures for the project were, they were nevertheless "full of errors; and the reason is that he does not command any draughtsmanship." 28

Given that Cellini's relief in bronze appears to have been added expressly to measure his expertise in this specialized field of sculpture against that of his closest competicors, past and present, one wonders what constitutes the relicf's superiority. Perseus Liberating Andromeda, as Avery observed, is a failurc in terms of pictorial or graphic relief possessing the depth of illusionistic painting or perspectival drawing. His connoisseur's eye seized upon its apparent shortcoming: the shallow rclicf of the central running figure creates a flagrant lack of depth at the center of the composition. Instead of allowing the viewer's eye to move naturally and gently into the far background toward a vanishing point, as do Donatello's or Ghiberti's gradually Hattened pictorial reliefs, the low relief of the angry figure blocks penetration of the picture plane's surface while at the same time it implies an awkward recession in depth and distance. But this may well be the point: the relief's formal incongruity reveals the limitations of the genre. Bas-relief remains an art of surface, a kind of sculptural sketching closer to the two-dimensional arts of drawing and painting. And Cellini's purpose is not so much admiring imitation, as critical appraisal of the nature of his predecessors' accomplishments.

Adding greatly to the anti-spatial quality of the naked man is his proximity to the fully rounded figure of Andromeda. The contrast between figural relief sculpture, which is modelled in depth and projected outward toward the spectator, and relief sculpture, which is barely scratched on or into a surface to create the illusion of depth, could not be more marked. The male nude functions as a foil for the three-dimensional bcaucy of Cellini's Andromeda who, though a chained captivc, nevcrtheless moves freely in space, twisting her torso and face toward the foreshortened runner with splendid plasticity. Rather than assuming the standard pose of a petrified victim chained upright to a rock or cliff, Cellini's Andromeda is seated and almost fully modelled in the round. ${ }^{29}$ Her seated pose answers the runner's upright pose, for both raise their right arms above their heads.
As Andromeda swings toward the angry man, only her left side, the chained side nearest him, remains embedded in the surface of the relief. She appears to be a mobile, three-dimensional volume in space with air circulating about it, whereas the running man is ghostly, a mere ripple across the plane of the relief. Together they form a pair of contraries at the heart of Cellini's bronze relief.

Andromeda's freedom of movement and palpable, tangible form condemn to the unreal space of graphic or pictorial art the male nude with whom she disputes the geometric center of the relief. Viewed at close range, his irruption may appear to have pushed her to one side of her rocky perch, but seen from a distance the aggressive runner is quite simply invisible, leaving blank the center of her pedestal and of the relief. 'This strategic lack of symmetry along the frontal axis of the ensemble of the monument is explained by Cellini's desire to challenge the masters of drawing and the planar art of relief sculpcure while at the same time comparing unfavourably their draughtsmanly and graphic sculpture with figural sculpture in the round, deemed by him superior, and far more difficult to execute. ${ }^{30}$ Following the sculptor's visual logic, only the "real" hero of the relief, the projecting air-borne Perseus, can save Andromeda, since the running nude lacks the existence conferred by the third, the heroic and sculptural, dimension. "Being born of relief, I must raise it up and praise it for it is the most marvellous of all things," affirms Cellini in Sopra l'arte del disegno. ${ }^{31}$

\section{Sculpture and Architecture}

Drawing and painting are not the only arts referred to in the relief for the sake of comparison, of incroducing paragoni. The decidedly two-dimensional architccturc in the upper right corner of Perseus Liberating Andromeda (fig. 1) has little mythological justification, and like the naked runner, it has probably been included as much to invoke another art form as to enhance the political content of the relief. 32 Architecture's place in Cellini's oeuvre has scarcely been studied nor has his attitude toward it received much attention, for the goldsmith-sculptor did not actually practice architecture, which does, though, figure in his later technical and theoretical writings. 33 In Cellini's brief commentary tracing the genealogy of the arts in a proposal for a seal for the Florentine Accademia del Disegno, architecture occupies a dependent and derivative position. It is described as the "sister" of painting, and "second daughter" of sculpture, the father of the arts. 34

The inclusion of a series of antique monuments in the background of the "sketched" half of Cellini's relief encourages reflection on the unequal relationship between the arts of sculpture and architecture, and helps to define the latter as an art of line akin to drawing and painting. Disembodied monu- 
ments float above the heads of the figures rather than serving to demarcate a ground line and to effect a rational and measured recession in depth. The tiny cityscape is no more effective than the running figure at capturing the viewer's attention from a distance or leading the eye into the pictorial surface toward a distant vanishing point deep behind it.

Cellini's short treatisc on architecture, Della architettura, provides additional cvidence of the inequality existing between the arts of sculpture and architecture. Written before 1567 and meant to complement his theoretical and technical writings on art, Della architettura affirms that painters and sculptors alike have practised architccture successfully as, indeed, have buttonmakers. The tale of a Ferrarese merciaio, who turned architect on the strength of a few sketches and a little reading, and adopted the name maestro Terzo to indicate he was the third great architect after Bramante and Antonio Sangallo, does little to recommend the art. ${ }^{35}$ Architecture, according to Cellini, is like button-making a "utilitarian" art, whose primary purpose is to protect and shelter man as do clothes and armour. It becomes an admirable thing, cosa mirabile, when it serves as a support for "ornaments," that is, for sculpture. 36 The supporting role of architecture in relation to sculpture is echoed perfectly in the overall structure and content of Cellini's treatise, which ends with an encomium of his Perseus. Similarly to admirable architecture, the treatise serves as a context or framework for the display of sculpture. 37

The history of archicecture contained in the treatise is largely a history of writing about architecture, which reinforces the notion of a draughtsmanly and book-learned art, and affords Cellini an opportunity to discuss a copy of a Leonardo da Vinci manuscript that he had acquired in France. As described by Cellini, Leonardo's manuscript is devoted mainly to the science of perspective, that is, to the drawing of illusionistic buildings on a two-dimensional support, rather than to the construction of actual buildings in space. In fact, the manuscript belonging to Cellini epitomizes what might be called the painter-draughtsman's approach to the art of building: it is a theoretical work written on paper by a painter, rather than a stone edifice or even a wooden maquette. And it describes the art of creating with line drawn on a surface the illusion of three-dimensional buildings - the very type of virtual architecturc present in the Andromeda relief, and implied by the placement of the relief on the flat wall of the Loggia. The weightless buildings of Cellini's relief are not designed for habitation and lack sculptural ornamentation. If architecture's role is to accommodate, protect, and frame mankind and his sculpture, this is the useless, imaginary architecture of pure line. And it is flawed similarly to the running figure because it projects unconvincingly outward toward the spectator rather than drawing the eye into the background as do the "sketched" facades of Donatello's St. Cieorge relief (fig. 5). As a consequence, the background architecture of Cellini's relief scems to attempt in vain what his deeply carved figures successfully achieve.

If the architecture pictured in Perseus Liberating Andromeda is intangible and uninhabitable, if it is the linear architecture of the draughtsman-painter, then Perseus's marble basc is bettermore sculptural and three-dimensional-architecture, custom built to house sculpture, as prescribed in Cellini's treatise. Possessing volume and molding space to serve statuary, the base is nonetheless defined by plane geometry, by flat walls or planes bounded by lines (figs. 2, 3, and 7). It resembles a miniature cubic house with four distinguishable faces or facades, each perforated by an arched niche containing a small bronze statuc. It functions as utilitarian and real architecture vis-à-vis the statucs, but of an especially ornamental type deriving from sculpture and deferring to the human figure. As such, it teaches the vicwer the proper relationship between sculpture and architecturc, a relationship in which sculpture dictates architecture's form and function.

The exemplary, sustentative architecture of the base symbolizes the supcriority of sculpture in a second way, since Cellini designed it to have the principal quality distinguishing sculpture from the other arts. ${ }^{38}$ Sculpture, the most difficult of the arts, must possess "eight views" ("otto vedute"), all "equally good" (of "egual bontà"), declared Cellini in a now famous letter to Benedetto Varchi. ${ }^{39}$ In later writings he would increase this number upwards to forty, to one hundred, and to infinity. 40 Cellini's pedestal was designed to be seen advantageously from eight not four angles, the four faces of the cube and its four corners. Ephesian Dianas, enriching the corners of the base, serve to mark the four additional or subsidiary viewpoints. Because it possesses only one veduta, the Andromeda relief marks the point of departure for assessing the challenge involved in executing sculpture as opposed to art in two dimensions. The single optimal viewpoint of the relief completes a progression from ground to summit that could be expressed in terms of the formula: $1>4-8>40-100>\infty$. Thus, instcad of limiting to one the number of angles from which the Perseus on its base was meant to be appreciated, the relief underlines the incompleteness of the pictorial arts to which, in Cellini's theory, even admirable architecture belonged, inasmuch as it was not an art of the living figure, but of the static and flat wall, a planar construction with a finite number of viewing angles.

The bronze rclicf thus serves to fix the Perseus statue on its pedestal within a two-dimensional, architectural frame, orienting them frontally through the creation of an Albertian pictorial or one-point perspective. But the relief sculpturc of Perseus Liberating Andromeda adheres to the sculptural cnscmble above without being necessary to it or enjoying the freedom in space of either the statue's or the pedestal's three-dimensional forms. And even from a frontal perspective the Perseus does not respect 


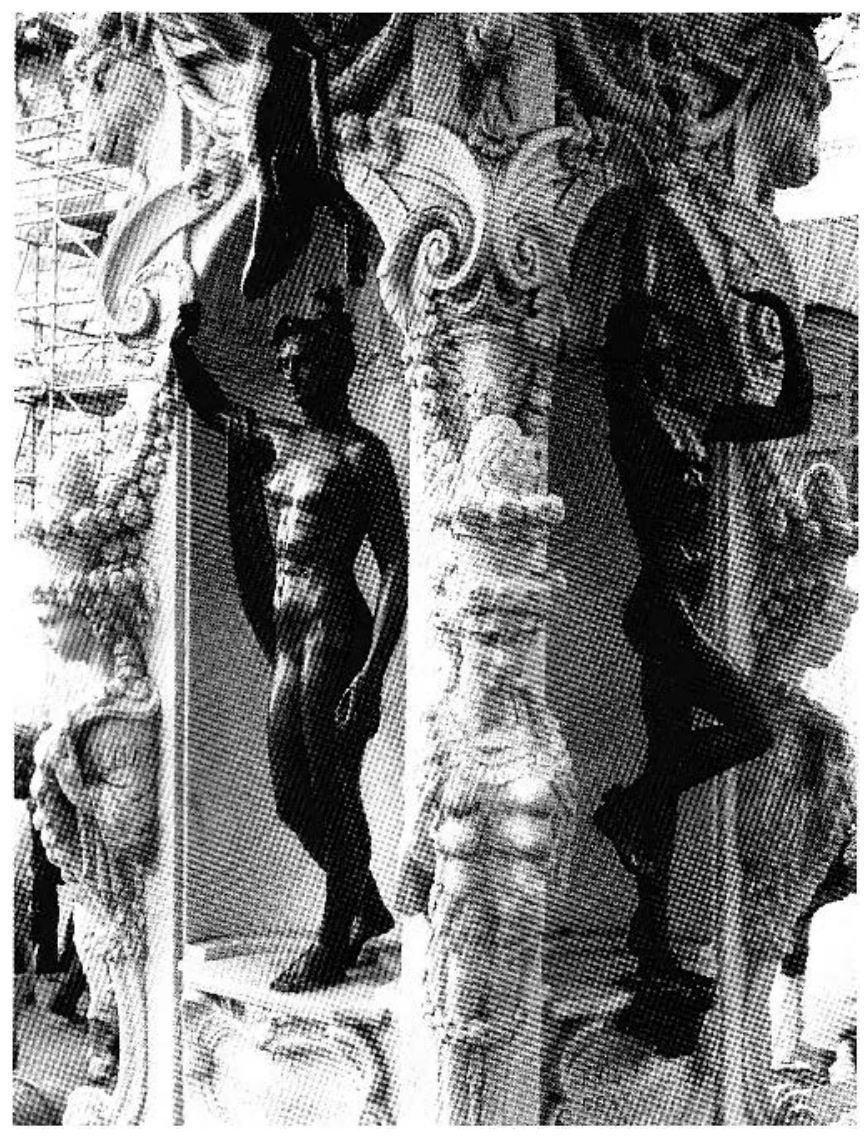

Figure 7. Benvenuto Cellini, replica of the base of Perseus and Meduso, 1545-54, view with Mercury and Minerva. Marble and bronze. $199 \mathrm{~cm}$. Loggia dei Lanzı, Florence (Photo: author).

the wall fixed by the plane of the relief and the masonry balustrade of the loggia, since the giant statue leans forward and out from under the Loggia's roof, just as all the male statuettes transgress the walls of the base by stretching up or reaching out from their niches. Mercury (Perseus's half-brother) escapes simultaneously from the smoothing protection of clothes, armour, and from his architectural niche, a fact underlined by the inscription underneath him: "So you may bear a brother's arms, I fly naked to the stars" 41 (fig. 7). The goldsmith-sculptor's desire to liberate statuary from surface is even more cvident in the small wax model for the Perseus than in the finished bronze, since the slender wax hero seems to have alighted only momentarily on the earth's crust before beginning again to climb skyward. 42

\section{Liberating Andromeda}

In Cellini's day Michelangelo's David and Bandinelli's Hercules stood in the open air of the Piazza della Signoria, as had for a time Donatello's Judith and Holofernes. But because it was built into the balustrade or partial wall and the floor of the Loggia, Cellini's Perseus was never technically a freestanding work independent of an architectural frame in the same way as were those with which it was seen to be in competition. And yet, despite having been specifically conceived for and anchored in the architecture of the ducal square, the Perseus is not a secondary element dependent for its impact on a particular architectural framework, as viewers who saw it indoors during the recent restoration can attest. ${ }^{43}$ Rather, the huge bronze statue accomplishes the seemingly contradictory task of fastening itself to an architectural environment, while at the same time proclaiming the artistic primacy of freestanding sculpture.

Cellini's bronze relief is critical to the performance of this paradoxical feat, and a brilliant device, because it cements the statue and its base into the fabric of the Loggia, transforming them into a site-specific work, even as it pictures at its center a victimized statue, Andromeda, attached to the architectural wall. Andromeda is triply chained, to the stone pediment pictured in the relief, but also to the relief plane which contains her pediment and has become itself part of the balustrade wall of the Loggia. Sculpture's autonomy is menaced and its beauty is hidden by architecture's flat walls, and the sculptor's duty is to set it free. Nevertheless, a statue's literal chains can also be proof of the work's lifelike presence and thus of the sculptor's mastery: in antique and Renaissance legend fabulous statuary came to life in such a threatening way that it sometimes had to be put in irons. Such restraints were emblematic of the captive statue's all too successful mimicry of nature, as were the birds that pecked at Zeuxis's illusionistic grapes. The single chain of Cellini's Andromeda, then, indicates both the conflict between sculpture and architecture and the realism that sets sculpture apart from the other arts. Ironically, there is no need to restrain the running man, who-despite furious effort - will never put any distance between himself and the wall. Lacking the crucial third dimension, he is destined to remain ineluctably its prisoner.

As the eye travels upward through the three levels of Cellini's monument there is a gradual release of the sculpted figure from architectural incarceration. Compared to the relief figures in Perseus Liberating Andromeda, the small bronze statues relate in a less conflictual and more harmonious manner to the "better" architecture of Perseus's base. They appear able to move away from the concavities in the base's walls, which nevertheless shelter them and hide their backs. Their capacity to pull away from surface and wall is in between that of the tiny figures in relief and the giant Perseus. However, even the relative independence of the figures cast in the round compared to the figures cast in relief does not explain entirely why a goldsmith-sculptor, intent on asserting sculpture's ascendancy over architecture, would go to great lengths to attach bronzes sculpted in the round to an edifice. 
An autobiographical passage helps to clarify the issue. In the Vita, Cellini tells of displaying to his patrons, the Duke and Duchess of Florence, the four small bronzes for the base, figures of Jupiter, Mercury, Danaë, and Minerva, as though they were autonomous works. But this preview backfired when the Duchess exclaimed, "I don't want you to waste those statues by throwing them away on the pedestal down in the piazza, where they'll risk being spoilt." 44 To prevent his monument from losing several of its key elements, the artist promptly soldered the small bronzes into their niches in the marble base. He thus chose to forge chains of his own fashioning, rather than to allow his works to be imprisoned by the Duchess in her apartments. 45 Recounting the episode after the fact in the Vita operates both to assert his statues' independent beauty and to justify their relative thralldom.

The aesthetic appeal and self-sufficiency of freestanding statuary, though desirable, make it vulnerable to the designs of others. And Florentine sculptors had every reason to fear the usurpation or displacement of their works, since Donatello's Judith and Holofernes had already been moved twice before it was settled in the arcade on the west end of the Loggia, from which it would be ousted by Gianbologna's Rape of the Sabine in 1583.46 Today the Judith is not even present in the form of a copy in the piazza, and resides instead inside the Palazzo Vecchio, formerly the ducal palace. Michelangelo's David, now in the Accademia museum, was never placed in the ecclesiastical niche for which it had been intended. Upon the statue's complerion, a committee that included Cellini's father studied the problem of its placement before the decision was finally reached to position it to one side of the entrance to the Palazzo della Signoria. Michelangclo's companion piece to the David, which was to have stood at the other side of the entrance, was supplanted by Bandinelli's Hercules and Cacus before it had advanced beyond the stage of a clay model. Although, after the return of the Medici in 1512 and 1530, Michelangclo's republican David was allowed to retain its position of sentinel before the Palazzo Vecchio, Bandinelli's much-resented Hercules might not have survived the disappearance of the dynasty that commissioned it. At the age of 45 in 1545. Cellini was old enough to have witncssed the ups and downs of the House of Medici and to fear that vicissitudes of political fortune might affect a work commemorating Cosimo de' Medici's despotic regime. Soldering his Perseus to the Loggia with the bronze relief, as he had the smaller bronzes to the base, helped to prevent it from being re-appropriated and moved about the city like a piece on a chessboard. Paradoxically, to insure the large bronze's autonomy, the monument as a whole was rendered to a greater degree immoveable and site-specific through the addition of Perseus Liberating Andromeda, which at the same time pleaded eloquently for the emancipation of sculpture from the domination of architecture and the other arts.
At close range, at "reading" distance for the spectator standing in the piazza, the eye is drawn into the debate concerning relationships of dependence and inferiority among the arts by way of the sketchy running man and his fully rounded partner at the center of the relief. These two figures serve not only to introduce two disparate and unequal approaches to relief sculpture, but also to contrast drawing with sculpture and sculpture with architecture. Moreover, in relation to the rest of the monument, the pair sets in motion a series of comparisons that distinguishes varying degrees of excellence within the graphic arts and sculpture. In other words, the allegory of the arts built into the piazza is hierarchical in its presentation of the arts of sculpture, painting and drawing, and architecture, and discriminatory in its establishment of a scale of values applicable within these artistic domains. Drawing and architecture are to be admired insofar as they distance themselves from the tyranny of the picture plane and imitate sculpture in the round. The modelled and tactile three-dimensional human form represents the highest expression of the visible, tangible, and divinely ordered Creation, whose acme, central actor, and "ornament" is man; therefore sculpture becomes the standard by which all the other arts must be judged, which is why Bandinelli's disegno could not serve as a measuring stick for evaluating his Hercules statuc. ${ }^{47}$

\section{Sculpture and Painting}

Freeing sculpture from the hegemony of the other arts also meant freeing it from subservience to painting and the literary arts. The humanist and amateur painter Leon Battista Alberti had in his On Painting hailed painting as "the mistress of all the arts" including architecture, maintaining that architects, stonemasons, sculptors, and "artificers" were merely "guided by the rulc and art of the painter" and lacked the distinction accorded since time immemorial to painters. 48 Alberti and others argued for painting's entrance into the Liberal Arts on the basis of its mathematical foundations and of the recent advances in the science of gcometric perspective. Donatello had studied perspective with Brunelleschi, to whom On Painting was dedicated, and many of Donatello's works, especially those in relief, espoused a form of sculpture that seemed to allow painting to be sculpture's mistress. Because in Cellini's gendered vision of the arts, sculpture was lord and father, whereas painting occupied a derivative and dependent position, Perseus and Medusa's reversal of the female-male relationship of Donatello's Judith and Holofernes overturned symbolically the dominance painting seemed to have gained over sculpture during the quattrocento. ${ }^{49}$

But the reversal of power relations between the sexes in the piazza also responded to the more current debate claiming the place of honour for disegno, a position that surreptitiously increased the prestige of two-dimensional art. If disegno as 




Figure 8. Giorgio Vasarı, Perseus Liberating Andromeda. 157072. Oil on slate, $117 \times 100 \mathrm{~cm}$. Palazzo Vecchio, Florence (Credit: Scala / Art Resource).

design, project, intention, idea, or concept could claim to be fundamental to all three visual arts, as drawing it was necessarily an art of the pen, like poetry, which had more in common with the two-dimensional arts of painting and architecture than with sculpture. Drawing was clean, quiet, and physically undemanding and thus more easily defended as a noble, inrellectual pursuit. Il Cavaliere Bandinelli's cry of "what about my disegno?" is symptomatic of a sixteenth-century trend that devalued technical and material aspects of art and art-making in favour of spiritually or intellectually inspired content. 50 The successful artist became more than ever a designcr, teacher, and courtier at the head of a workshop who supplied apprentices and collaborators with plans to be executed. Consequently, a draughtsman-painter like Rosso or Primaticcio might produce the studies for the sculptural components of a decorative program. Repeatedly, Cellini insists in the Vita that he is not interested in making jewellery or sculpture from others' designs, especially non-sculptors' verbal instructions or drawings.

In this social context, the paragone debate becomes a struggle for control over all the phases and the ultimate fortune of one's art, rather than an empty parlour game. Cellini, who had been, according to his enemy Vasari, "in every action spirited, proud, vigorous, most resolute, and truly terrible," could not have allowed the disegni of a would-be gentleman painter-writer like Bandinelli to interfere with his work in the cathedral or elsewhere. ${ }^{51}$ It is also unlikely that Cellini's relief sculpture was intended to ape in an adulatory fashion any other art form in a high profile public setting. However, his Perseus Liberating Andromeda is framed like a painting in an obvious allusion to that form of art. Although the allusion has not gone unnoticed by art historians, the nature of painting's rclation to sculpture as articulated by Cellini's ensemble on the piazza has not been examined in sufficient detail or depth. After all, the precise question debated by artists at the behest of Benedetto Varchi in 1546 was which of these two art forms was nobler, painting or sculpture, and Cellini's quarrel in 1564 with the other organizers of Michelangelo's funeral concerned the symbolic displacement of sculpture by painting. 52

Given painting's perceived close link to poetry in Renaissance theory, it is appropriate that the handling of the traditional iconographic theme of Cellini's relief, as well as its form, bear on painting's case. Moreover, in the sixteenth century, Ovid's verses describing Perseus's rescue of the Ethiopian princess Andromeda from the sea monster Cetus furnished a topos, a readymade site or context, for comparing the arts, especially the art of painting to that of poetry. 53 Perseus symbolized the painter who, aided by the tutelary deities Minerva and Mercury, could vivify, could bring both colour and movement to the pallid flesh of Ovid's marmoreal, frozen heroine. Allegorically, Andromeda was Beauty liberated by the painter's love and chivalric valour from nature's monstrousness. Thus, the very subject matter of Cellini's bronze relief, like its framed and flattened form, evoked the art of painting for his contemporaries, even though the relief remained sculpture.

Not content with the conventions of an allegory tailored to praise painting, Cellini reinvented the pictorial theme of the Liberation of Andromeda in terms of both forme and fond: Andromeda became in his hands a specifically sculptural Beauty freed from the picture plane, and therefore from the constraints of point, line, and plane. This beauty is called into being not through the application of thin veils of colour bounded by line in the fictive depth of a window-like space, but rather through the molding of tangible substance and shape in the real space in front of the pictorial plane. Andromeda rises from the shiny surface of the relief to penetrate the viewer's space as does Perseus, both her rescuer in the relief and the thoughtful giant above.

The giant Perseus looks reflectively downward directing the viewer to consider what lies beneath his feet: Medusa's dying body, the mirroring surface of Minerva's shield lying upon his cape, and below these the watery nether regions of Cellini's base, with its Ephesian Artemises whose feet are framed by puddles. ${ }^{54}$ Artemis-Diana was a pagan nature goddess and planetary 


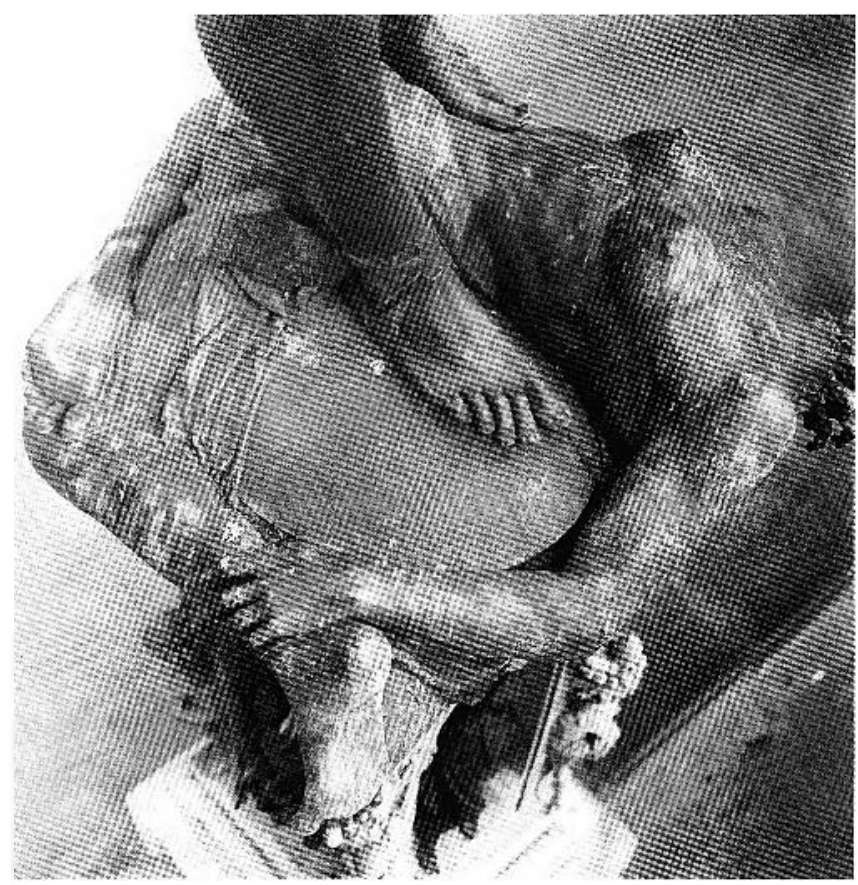

Figure 9. Benvenuto Cellini, Perseus and Medusa, 1545-54, detail with Medusa's body viewed from above. Bronzc and marble. Loggra dei Lanzi, Florence (Photograph by David Finn).

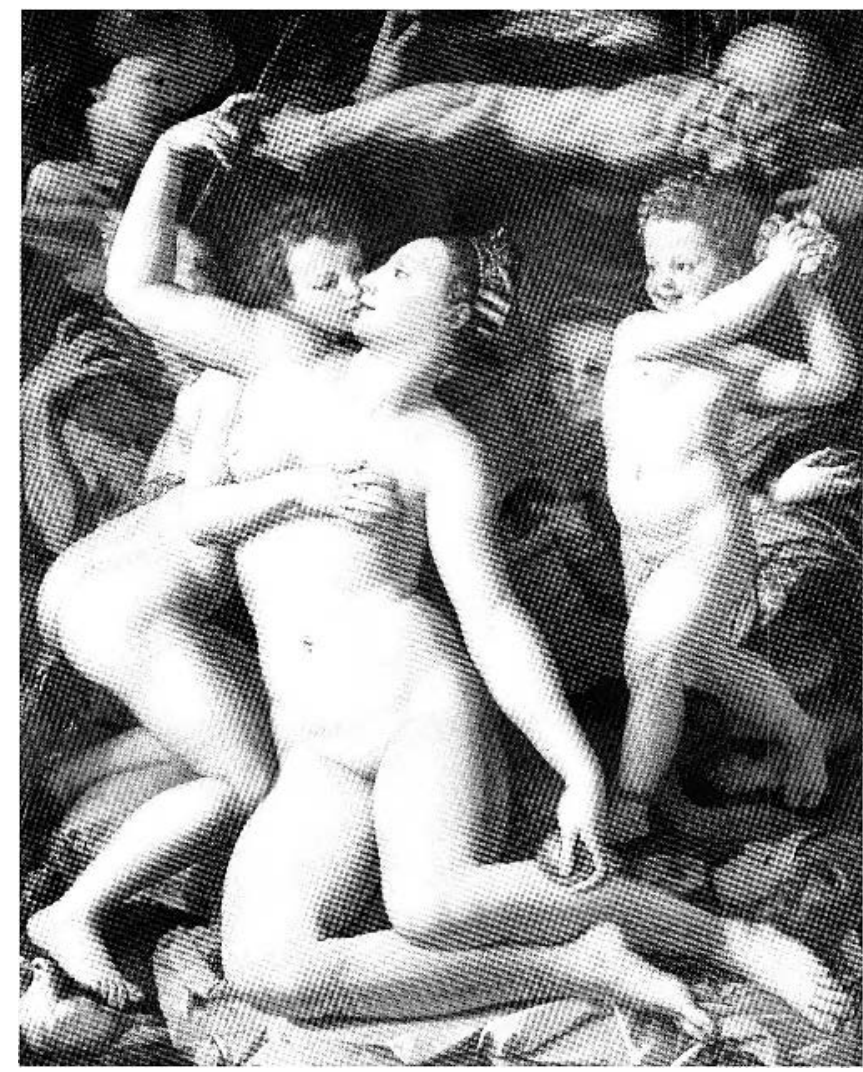

Figure 10. Agnolo Bronzıno. An Allegory with Venus and Cupid, 1540-50. Oil on wood. $146.1 \times 116.2 \mathrm{~cm}$. National Gallery, London (Photo: The National Gallery, London).

Andromeda theme. Perseus's shield lies on the ground reflecting the landscape as though it were Alberti's pool in Vasari's painted version of the rescue (fig. 8). 57

Alberti also identifies Narcissus, who admired lovingly his mirror image in a fountain, as the "inventor of painting." The resemblance between the poses of Cellini's Perseus and his marble Narcissus has been noted. ${ }^{58}$ Both statues seem to gaze downward toward their mirrored images, but in Perseus's case the most obvious mirror is Minerva's shield or aegis rather than the other liquid surfaces, which helps to identify him as personifying Prudence. The virtue prudence was particularly associared with the armourcd maiden Minerva, who could be identified by her mirror and Janus-face, as well as her shield and lance. Raphael's Stanza della segnatura shows the goddess between Temperance and Forritude looking into her mirror of self-knowledge while an old man's face gazes from the back of her head. But if Cellini confiscates Minerva's mirror as well as her shield for Perseus, it is not simply to supplant a female personification of wisdom with a male one, but to connect the two heroines of Ovid's myth, Medusa and Andromeda, in a double 


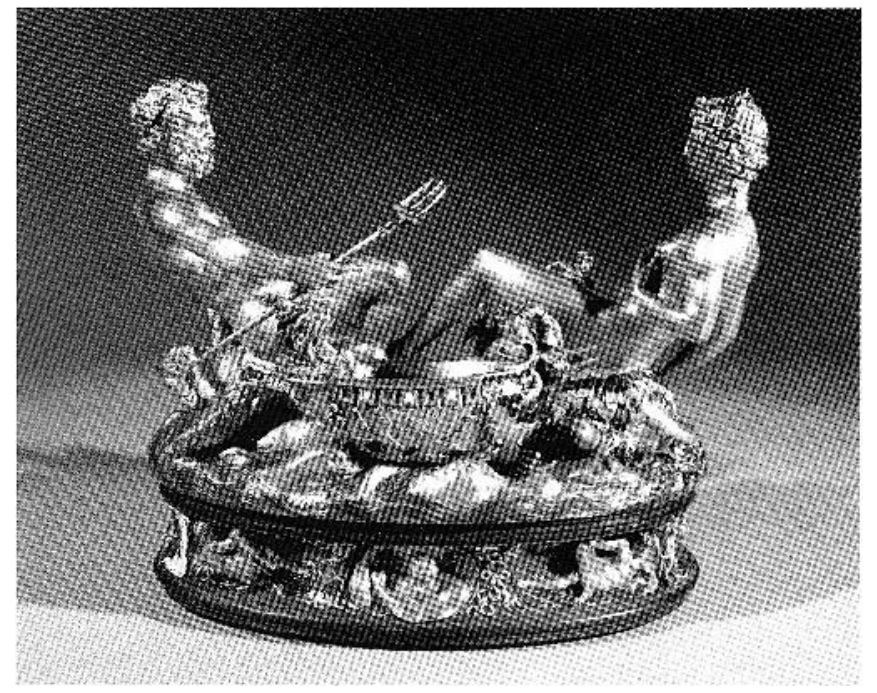

Figure II. Benvenuto Cellını, Saltcellar for Francis I, 1540 43. Gold and enamel, $26 \times 33.5 \mathrm{~cm}$. Kunsthistorisches Museum, Vienna (Credit: Erich Lessing / Art Resource, NY)

allegory of painting. Although Andromeda is immediately recognizable as a "painted" heroine, thanks to the marble frame of the relief, Medusa needs the polished mirror of Mincrva's shield to make herself analogous to Andromeda. 'The polished surface of Minerva's shield and Medusa's flattened and folded body are the ground from which the victor rises triumphantly in the round. Seen from above, from Perseus's "aerial" perspective, Medusa's body hugs the top surface of the pedestal to form a square frame around the circle of the shield's smooth, lookingglass surface (fig. 9). 59 As it loses its life's blood, the body is in the process of deflating to fit the geometry of the pedestal. In death it will join the two-dimensional world of the carth's and the sea's barely convex surface. But meanwhile, still half-alive, Medusa is a figure in high relief.

Ihe parallel between Medusa's body seen from above and certain of Bronzino's paintings, such as the Allegory with Venus and Cupid in the National Gallery (fig. 10), has long been apparent to art historians, ${ }^{60}$ who have nonetheless failed to consider the top plane of Cellini's base as a second allegory of painting. Understood as a second bas-relief, Medusa's dying body forms the pendant to Andromeda's almost entirely quickened and liberated form. From Perseus's point of view both are "faceless," female nudes with "mirrors," in Medusa's case the mirror of Minerva's shield and in Andromeda's that of the sea. And both female nudes exemplify the best and noblest type of painting, painting with sculptural values, which is exactly what Bronzino's statuesque figures with their hard, polished contours represented for his friend Cellini.61
Only the head of Medusa, saved by the sculptor's art from the limitations of surface, from Alberti's pool, will survive in its terrifying dimensions. Fittingly, Medusa's head enjoyed an afterlife in myth and legend that her body did not possess. Its blood gave birth to the precious marine "mineral" coral, which was believed to be capable of warding off the evil eye, and it became a potent weapon used by Perseus to slay his enemies. Then he made a gift of it to Minerva-Athena, female goddess and protectress of the polis, who placed it as an apotropaic motif, the Gorgoneion, on her shield or aegis. But the reflective surface the goddess lent to Perseus was only a blank field allowing the hero to trick the monster by gazing at her unreal and thus harmless reflection, instead of succumbing to the fatal stare of her very real head. Minerva, traditionally the patroness of painterarchitects, as Raphael's School of Athens attcsts, aided Pcrscus in his quest, but it is the sculpror-hero who has wiclded Mercury's curved sword to provide to Minerva's acgis, to painting, its real force, the seductive terribilità of the third dimension.

The difference between painting and sculpture for Cellini is the difference between a real and tangible thing and its reflection or shadow. ${ }^{62}$ Drawing and the other two-dimensional arts may assist Perseus in the performance of artistic fears, but they are subordinate compared to the act of modelling in clay and casting fully three-dimensional figures in bronze. Mutable maternal Nature is the raw material of the sculptor's art, as the Ephesian Dianas on Perseus's base suggest, but the sculptor must transform the four Aristotelian clements comprising the natural world rather than passively mirror nature's monstrous, external appearance. Even the hideous gorgon, transmuted by the sculpror's know-how, can become a gorgcous human bcing made not in the image of nature, but in that of God and man. Perseus's crowning accomplishment as artist-hero is as sculptor holding the astonishingly beautiful, fully threc-dimensional head of Medusa out into the open air of the piazza and of the world. At the moment of his ultimate triumph the head has lost its feminine specificity and is a sphere dangling almost free in space from above and visible from 360 degrees. Its silent lesson is that sculpture in the round possesses potency and immortality, which arts like bas-relief and painting, deriving from it, can never hope to match. ${ }^{63}$ Medusa's head was after all also an astral body, the bright and baleful star Algol, part of the constellation of Perseus. 64

The scale of aesthetic values established in the public piazza is identical to that in the Saltcellar for Francis I and in Cellini's later autobiography and his treatises (fig. 11). 15 On the base of the Saltcellar are reclining figures representing the Times of Day, quoted in golden relief from Michelangelo's Medici tombs in the church of San Lorenzo. ${ }^{60}$ But Michelangelo's reclining allegories are slaves of the picture plane, whereas Cellini's own versions of the reclining male and female nude emerge trium- 
phant into the ambient air to be admired from all angles. 'The fact that the Saltcellar possessed tiny ball bearings in its base, and could be rolled about on a table, made even more apparent its homage to sculpture in the round, to sculpture that stands free of the plane or wall and seems capable of moving frccly in space.

The superiority of mobile, freestanding statuary is further illustrated in the Vita's account of Cellini's unveiling of his lifesized silver Jupiter in the Gallery of Francis I at Fontainebleau. ${ }^{67}$ The silver statue, draped and holding a candle, seemed to advance toward the king and his entourage of its own volition due to the litcle rollers the artist had placed under its base. 68 'The long hall was lined with other statues, but also decorated with paintings and stucco reliefs by fellow Italians, among them Rosso and Primaticcio, painter-decorator and favourite of the king's mistress, the duchess of Etampes. Cellini's work triumphed because it stood out from these works as from so many lifeless wallflowers. And when the duchess of Etampes attempted to draw attention away from the Jupiter to the sculpture along the walls, Cecllini angrily ripped the veil from its loins to reveal his statue's masculine relief. 'I his provocative gesture, the revelation of the statue's hidden relief, silenced for once Cellini's bitter critic, the duchess, who could only sputter in anger.

Metaphorically removing the veil from his splendid Perseus, Cellini hoped in Florence to silence forever all enemies and detractors as he had his nemesis in France. As picture plane, the Andromeda relief at the bottom of the Perseus, borrowing from both painting and poetry, is this metaphorical veil or gloss on the true beauty of the malc nude. It is painting's deceitful, feminine surface without depth, which hides the self-evident "masculine" reality of both sculpture and the visible world. Painting is for Cellini a lie, "bugia,"69 but one instructive as a point of reference for the truth of sculpture. As one looks along the monument's vertical axis upward from the running man with his flattened sail-like drapery to the Jupiter and then to the Perseus on top, the "veil," the obscuring plane, is gradually lifted fore and aft from the male nude to reveal integrally his relief (fig. 2). The partially draped figure of Jupiter on the base of the Perseus constitutes an intermediate phase of masculine unveiling, whereas the angry runner-lowest on the totcm pole of statuary-remains completely "veiled" despite his nudity: he is rendered bidimensional and emasculated by the femininity of the form of art in which he is executed. Considered within Cellini's gendered hierarchy of the arts, the running nude's body is less sculptural than are even the imperfectly liberated "painted" bodies of Andromeda or Medusa. Compared to victorious Perseus, he is a lie, whereas the women are merely half-truths.

\section{Killing Medusa}

Bodics fused to the pictorial field are not the only formal characteristics that reveal Andromeda and Medusa to be oppositc sides of the same bad coin. The two female nudes are linked formally by the streaming and gushing movement of their hair and blood. Andromeda's sculpted hair flows out from the back of her head in an aggressive point or arrow toward Perseus and the monster (fig. 1), much as Medusa's blood spurts from her truncated neck into the piazza toward the spectator (fig. 2). The bcauty of femalc hair, that sinuous and linear quantity, was the cause of both Medusa's and Andromeda's misfortunes. Medusa had once been so beautiful that the sea god Poseidon rapcd her in Athena's temple; similarly Andromeda's mother, boasting of her and her daughter's beauty, had brought about Juno and the Nereids' wrath. Medusa was punished for the sacrilege by the transformation of her proud locks into repulsive snakes, whereas Andromeda was to be sacrificed to atone for her morher's hubris.

More significant still, for apprehending the complementarity of the two heroincs, is Andromeda's offering of her forelock to the angry running figure in a gesture common to sixteenthcentury personifications of Occasio, Good Fortune or Opportunity. Andromeda, in the role of capricious but attractive Good Fortunc has turned away from the hero, whereas Medusa in the role invidious Ill Fortune has twisted toward him to use her deadly gaze. The bcautiful face of Good Fortune, Andromeda, favours the irate runner rather than Perseus, who will nonetheless win her through his courageous efforts. Again and again the Vita stresses that the goldsmith and his unlucky Perseus, "isfortunato Perseo," unlike Cellini's Medici patrons and fellow artists, are not aided by Fortune and the stars. ${ }^{70} \mathrm{When}$ Cellini loses the commission for the Neptune statue in Florence he sends the winner of the contest, Bandinelli's follower Ammannati, a message urging him to "work very hard so that he could show his gratitude to Fortune for the very grcat and undeserved favours she was showing him."7l

Victory, no matter how virtuous and well deserved, was believed by Cellini and his contemporaries to provoke poisonous envy. The goddess of earthly happenstance, Fortuna, became jealous of those whom she had favoured and dashed down that which she had lifted on high. To remain victorious thus meant to vanquish envy, whcther it was the envy of celestial forces like Fortuna, or of the gods, or of onc's fellow mortals. In Vasari's painting, on the ceiling of his house in Arezzo, The Triumph of Virtue over Fortune, Virtue must seize the forelock of the fortunate Opportunity, a beautiful, young woman, while trampling underfoot Invidia, an ugly old woman with untidy hair and serpents coiled about her (fig. 12).72 Bronzino's painting, too, includes a dishevelled Medusa-like head of an old woman be- 




Figure 12. Giorgıo Vasari, Sala del Camıno frescoes with the Triumph of Virtue on the ceiling. Casa Vasari. Arezzo, 1548 (Credit: Scala / Art Resource, NY).

hind his lovely Venus to suggest that envy or madness succeeds love or lust (fig. 10).

Judging from both Vasari's and Cellini's testimony, envy was an especially fierce and frequent motivation in artistic circles. Vasari blames Bandinelli's envy and enmity for the destruction of Michelangelo's celebrated Battle of Cascina cartoon. ${ }^{73}$ For Cellini, disegno generated rivalry. In the commentary on what was presumably his final proposal for the seal of the Accademia del Disegno, disegno is of two kinds, one of the imagination and one of line. The disegno of line, fiery like the burning rays of the sun god Apollo, goads men to compere with one another. ${ }^{74}$ In assessing drawing's Apollonian "temperament" Cellini may be remembering the already legendary fresco competition that took place between Leonardo and Michelangelo at the beginning of the century in the Sala del Gran Consiglio of the Palazzo Vccchio. ${ }^{75}$ What was to have been a painting contest became effectively a drawing contest since both men finished only the cartoons for battle scenes, and these cartoons spawned further rivalry as Bandinelli's alleged theft of one of them proves.

Envious rivalry is also a major theme of the myth of Perseus and Andromeda as told by Ovid. The demi-god Perseus, son of Jupiter and Danaë, catches sight from the sky of a beautiful princess who has been abandoned by her people to appease a sea monster named Cetus. Juno and the Nereids, jealous of her and her mother's beauty, have condemned the daughter to death. In exchange for Andromeda's hand in marriage, Perseus kills the monster and libcrates the maiden, to the grateful joy of both watching parents. But much of Ovid's tale is not devoted to the romantic rescuc, but to its grisly aftermath, the ambush of Perseus at his wedding banquet by Andromeda's uncle and former fiancé, Phineus, at the head of his army. The jilted suitor seeks to murder the newcomer for stealing his bride and future kingdom. After having already slain monsters, Perseus must take on a whole battalion of furious warriors. Ovid's bloody verses recount how the hero dispatches them valiantly one after another before he concludes the unfair competition by resorting to the magical gaze of Medusa's head.

In concentrating the right half of his relief on the anger and envy of Perseus's numerous enemies, Cellini does not depart from Ovid in the narrative of his relief. But he does depart from the customary depiction of the myth of Perseus and Andromeda that separates, spatially and temporally, the rescue of the princess from the less frequently depicted battle scene. Typical, for example, is Perino del Vaga's frieze in the Castcl Sant'Angelo wherc the themes of Perseus Liberating Andromeda and Perseus Battling Phineus and his Men are shown in two distinct scenes. In one the hero kills the monster and in another he petrifies an army of assailants with Medusa's head. Similarly, Polidoro da Caravaggio's sketch shows only Perseus Battling Phineus and his Men in a separate scene (fig. 13). But Cellini need not destroy the spatial unity of his composition by recounting this second episode in the fictional genre of relief sculpture (i.e., in "painting"), since his colossal Perseus performs it in the public arena of the piazza. In the scenario enacted by Cellini's statues, blood flows copiously in the direction of potentially inimical spectators who are "turned to stone," mesmerized, in real space and time by the sight of the freestanding bronze holding out the magical "sculpted" head. Not tiny warriors in relief, but flesh and blood spectators in the piazza are this Perseus's victims, as well as the freestanding giants of Michelangelo and Bandinelli, whose petrified statc did not escape the notice of sonneteers praising Cellini's bronze warrior. ${ }^{76} \mathrm{~A}$ similar desirc for expedient artistic vengeance of the one against the many is expressed in the Vita when Cellini boasts, "By showing my skill in this way [making steel mcdals] and not with my sword, I added, I would slaughter all my enemies."77 Although the goldsmith-sculptor's best revenge on a multitude of various enemies, some personal, others cosmic, professional, or political, is the intimidatory gesture of his beautiful Perseus, his smaller Jupiter also aims a retributive thunderbolt in the direction of the piazza and of the men at arms below in the relief. Jupiter's inscription warns: "If anyone harms you, my son, I will avenge you."

The armed men in the relicf thus function also as a crowd of inimical spectators, but one not yet petrified by victorious Perseus's secret weapon. Either they are viewing the statuesque Andromeda from several vantage points, as Cole has suggested, or they are witnessing the rescue sccne as a whole taking place on the left. ${ }^{78}$ Because Perseus Liberating Andromeda functions as an allegory of the arts, the shallow figures are the invidious enemies of art and virtuous artists, that is, of art defined as an es- 


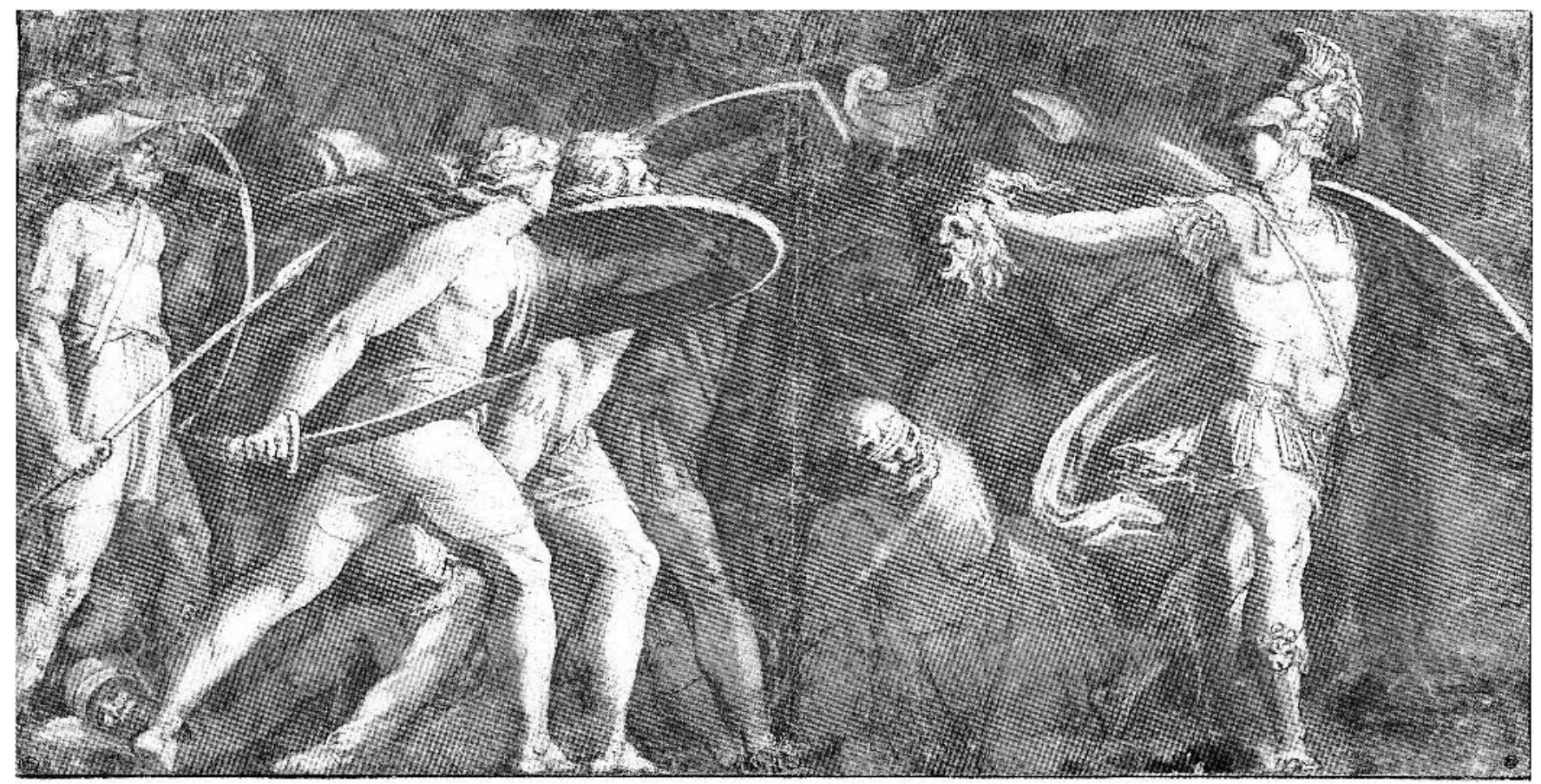

Figure 13. Polidoro Caldara (Polidoro da Caravaggio), Perseus Bottling Phineus and his Men, n.d. Pen and ink on paper, $22 \times 42 \mathrm{~cm}$. Louvre, Paris (Credit: Réunion des Musées Nationaux / Art Resource, NY).

sentially sculptural enterprise. Even the growling dog on the far right edge of the relief is a traditional symbol of the deadly sin of envy.79 In strictly visual terms these ill wishers are "painted" or "sketched" observers of the heroic "sculpted" tableau, for apart from Andromeda's distressed parents in deeper relief, the angry men are cast in low relief and shout and brandish their weapons in the direction of the deeply carved figures of Andromeda, Perseus, and Cetus.

In his short discourse entitled Sopra l'arte del disegno Cellini speaks scornfully of non-sculptors who, in praising painting, have spoken "like painted men, without relief." 80 Phineus's army is flattened and linear, as are its arms-lances or pikes like parallel lines that form a picket fence around the sketched city they seem to defend. Like the demonic warriors in the sky borrowed from Donatello and Leonardo, this army has sound and fury, but no real matcriality. The running figure at the center of the relief speaks or rather shouts "like a painted man, without relief," promoting through his very lack of substance the pictorial arts of drawing, painting, and architecture. His furia and terribilità are more caricature than compliment. ${ }^{81}$

Nonetheless there is for Cellini perhaps also some measure of self-recognition in the competitive rage of the running figure, which has sometimes been read as a second Perseus, or as the alter ego of the artist. Despite belittling Bandinelli's disegno as a means to achieving sculptural fame and as a substitute for good sculpture, Cellini, too, claimed excellence in draughtsmanship, especially in his youth, and competed to some extent with Bandinelli in this area, as the letter cited above suggests. ${ }^{82}$ In the second edition of the Lives Vasari immortalized Cellini in relation to Bandinelli as half of a warring pair. ${ }^{83}$ Vasari rcinforces this image of Celllini in the only known portrait of the artist, which shows him in the background behind the duke of Florence nose to nose with Bandinclli. Both men wear long white beards. ${ }^{84}$ Cellini's rivalry with Bandinelli and with artists whom he did not respect did not enhance his reputation. Ultimately, the competition with Bandinelli dishonoured Cellini since competing degnamente with Bandinelli was impossible, which is perhaps why Cellini never completed any reliefs for the cathedral. Just as Cellini was linked to but diminished by his arguments with Bandinelli before the duke, so, too, is the flying Perseus linked to the men on horseback of the diabolical skirmish ovcrhead who, like the running nude, are almost without relief. To take up arms that were not sculptural in defense of his art was to a certain degree to stoop to the level of his adversaries-although it also made more solid Cellini's nuanced claim to universality. Instead of producing his best work, as when in competition with Antiquity, Donatello, Michelangelo, or with his own earlier efforts, he sunk to name-calling and threats of violence. Perseus Liberating Andromeda was not his most perfect piece nor was its aim to eclipse his previous sculpture. 85 
In life as in art the sculptor joined reluctantly and belatedly the verbal fury surrounding the arts. Moreover, Cellini's relief as sculpted response conformed perversely to Michelangelo's advice to artists to stick to their art rather than wasting time on disputes about the paragone. ${ }^{86}$ In erecting the Perseus and Medusa, the artist had sought to place himself symbolically, like the old Michelangelo, hors concours and beyond the reach of envy. It is this destructive vice that his sculpturc eradicates preemptively before the eyes of those who would attack it. And if the victory of Perseus over this vice was not already clear to the viewer, the gloss inherent in the relicf's addition re-stated it in more emphatic terms.

In the dynamic of the tripartitc Perseus monument, the pictorial arts are overcome in order for the sculptural beauty of the freestanding male nude to assert its rightful place in the piazza. ${ }^{87}$ This place is claimed through aesthetic fact preceded by action and deed, not by word and concept. Verbal disputes among the arts and among artists, like so many venomous strands of Medusa's writhing locks, pose no real threat to sculpture's and the sculptor's dominance in the piazza. For when the spectator's eye and the poet's pen neglect the contentious Perseus I-iberating Andromeda to marvel in silence on the colossal bronze statue with his sculpted trophy, the goldsmith-sculptor has already, according to his own terms of engagement, won honour and avenged his art. ${ }^{88}$

\section{Dedication}

This article is dedicated to my mother, Ann Alder.

\section{Notes}

1 The original marblc base or pedestal of the Perseus and Medusa is now in Museo Nazionale del Bargello, as are the base's small bronzc figures and the Perseus Liberating Andromeda relief.

2 For the chronology of the casting of the various parts of the monument, see Michael W. Cole, Cellini and the Principles of Sculpture (Cambridge, UK, 2002), 48 and 72; and by the same author, "Cellini's Blood," Art Bulletin 81, 2 (June 1999): 215-33; and John Pope-Hennessy, Cellini (New York, 1985), 181-82.

3 Michael Cole cites Willem I)c Tetrode and Francesco del Tadda as two scarpellini in Ccllini's employ who may have been responsiblc for carving the marble base. Scc Cole, Cellini and the Principles of Sculpture, 83.

4 "... whereupon he executed in metal the statue of the Perseus that has cut off the head of Medusa, which is in the Piazza del Duca, near the door of the Ducal Palace, upon a base of marble wirh some very beauriful figures in bronze, each about one braccio and a third in height." Giorgio Vasari, Lives of the Most Eminent Paint- ers, Sculptors, and Architects, trans. Gaston de Vere, notes David E. Kserdjian (New York and Toronto, 1996), 885.

5 An exception is Color Plate 85 in Pope-Hennessy's Cellini, one of the few complete photographs showing the original marble base and the relief in situ. Today it is no longer possible to photograph all three elements of the original monument together, since the base and relief have been replaced with replicas. But the fact remains that photographs_older or more recent_of the ensemble as a whole are rare.

6 Ccllini's transformation into writer is traced in Paolo L. Rossi, "Sprezzatura, Patronage, and Fate; Benvenuto Cellini and the world of words," in Vasari's Florence: Artists and Literati at the Medicean Court, ed. Philip Jacks (Cambridge, UK, 1998), 55-69. For the Vita as "a calculated campaign of sclf-presentation," see Victoria Gardner Coates, "Ut vita scultura': Cellini's Perseus and the selffashioning of artistic identity," in Fashioning Identities in Renaissance Art, ed. Mary Rogers (Aldershor and Brookfield, VT, 2000), 149-61; and by the samc author, "'Homines non nascuntur, sed figuntur': Benvenuto Cellini's Vita and the Self-presentation of the Renaissance Artist," The Sixteenth Century Journal 28: 447-65.

7 Cellini describes the initial visual impression made by his works in the following pages of his Autobiography: 80 (morse), 270-71 (doorway), 271 (fountain), 237 (saltccllar). The passage in which the goldsmith recounts the genesis of his Saltcellar for Francis I and contrasts the dare of men of letters with the fare of his wax maquette (Autobiography, 237-39) has attracted the interest of scholars. Sec for example Corinne Lucas, "L'artiste et l'écriture: il dire et il fare dans les écrits de Cellini," Culture et professions en Italie (XVe-XVIle siècles), cd. Adelin Charles Fiorato (Paris, 1989), 67-97.

8 Benvenuto Cellini, Autobiography, trans. George Bull (I.ondon, 1956, 1996, 1998), 2. For the convenience of the reader quotations from Cellini's Autobiography or Vita will bc taken from the rcvised edition (1998) of Bull's popular translation. For quotations in Italian the text used will be Benvenuto Cellini, Opere, ed. Giuseppe Guido Ferrero (Turin, 1971).

9 Frwin Panofsky, Studies in Iconology. Humanistic 'Themes in the Art of the Renaissance (New York, San Francisco, and London, 1972; first published 1939), 14-15.

10 Sce Corinne Mandel, "Pcrseus and the Medici," Storia dell'Arte 87 (1996): 168-87.

11 For the relief's narrative characterizcd as "puzzling," see John PopeHennessy, Cellini, 181.

12 John Shearman, Only Connect... Art and the Spectator in the Italian Renaissance (P'rinceton, NJ, 1994), 44-58; and "Art or Politics in the Piazza?" in Alessandro Nova and Anna Schreurs, eds., Benvenuto Cellini. Kunst und Kunsttheorie im 16. Jahrhundert (Cologne, Wcimar, Vicnna, 2003), 19-36.

13 Cole, Cellini and the Principles of Sculpture, 128-48.

14 In Warburg's theory the Botricellian ninfa or dancing maenad was 
a key locus for experiencing the conflict (Auseinandersetzung) between Dionysian movement and Apollonian stasis in quattrocento Florentine art. In opposition to Panofsky's third and iconological level of interpretation, Warburg's kritische Ikonologie considers verbal or textual meaning to be an aid in the apprehension of visual expression, with formal and visual meaning arising from antagonistic energies manifest in the work. See the collected work in Aby Warburg, The Renewal of Pagan Antiquity: Contributions to the Cultural History of the European Renaissance (I os Angeles, 1999). Warburg considered his interdisciplinary approach to art history to be, fundamentally, a stylistic approach, as a fragment published by Gombrich reveals. See E.H. Gombrich, Aby Warburg: an Intellectual Biography, 2nd ed. (Chicago, 1986), 141-44.

15 For the paragone debate in Florence, sec Lcatricc Mcndclsohn, Paragoni. Benedetto Varchi's Due lezioni and Cinquecento Art Theory (Ann Arbor, MI, 1982). For Leonardo's contribution to the debate, see Claire J. Farago, Leonardo da Vinci's Paragone: a critical interpretation with a new edition of the text of the Codex Urbinas (Leiden, New York, 1992). Leonardo's writings on the rclative status of the arts are also grouped together and translated into English in Leonardo On Painting, eds. Martin Kemp and Margarct Walker (New Haven, 1989). For a general introduction to the Renaissance debate and translations of key texts into French, scc Laurianc Fallay d'Este, Le Paragone. Le parallèle des arts (Paris, 1992).

16 For the paragone debate as having two epochs of intensity, see Stephan Morét, "Der paragone im Spiegel der Plastik," in Nova and Schreurs, Benvenuto Cellini, 203-15.

17 Alessandro Nova, "Paragone-Debatte und gemahlte Iheorie in der Zeir Cellinis," in Nova and Schreurs, Benvenuto Cellini, 183-202.

18 Georges Didi-Huberman argues in favour of an approach to Renaissance art which is not based on identity in "Ihe Portrait, the Individual and the Singular: Remarks on the Legacy of Aby Warburg," The Image of the Individual: Portraits in the Renaissance, cds. Nicolas Mann and S. Syson (London, 1998), 165-88. Scc also Didi-Huberman, L'image survivante: histoire de l'art et temps des fantômes selon Aby Warburg (Paris, 2002).

19 Charles Avery, "Drawing in the Work of Renaissance Sculptors," Drawing 19, 4 (Summer 1998): 116.

20) The competition among statues in the piazza has been studied by John Shearman in Only Connect... Art and the Spectator in the Italian Renaissance, 55-57. For the rivalry between Ccllini and Bandinelli in general, see Rona Goffen, Renaissance Rivals. Michelangelo, Leonardo, Raphael, Titian (New Haven and London, 20()2), 34185. For the theme of rivalry in the Cellini's Vita, consult HansGünter Funke, "'Superare gli Antichi e i Moderni'-Das 'Thcma des Wettstreits in der Vita Benvenuto Cellinis," Italien und die Romania in Humanismus und Renaissance, eds. Klaus W. Hempfer and Enrico Straub (Wiesbaden, 1983), 17-37.

21 Giorgio Vasari, Lives, II, 885-86.

22 Ferrero, Opere, 823.
23 For disegno as Bandinelli's "strong suit," see Joanna WoodsMarsden, Renaissance Self-Portraiture. The Visual Construction of Identity and Social Status of the Artist (New Haven and London, 1997), 142.

24 Baccio Bandinelli, "Il memoriale di Baccio Bandinelli," Repertorium fur Kunstwissenschaft 28, ed. Arduino Colasanti (1905), 40643.

25 To view the self-portrait, see http://www.gardncrmuscum.org/collection/bandinelli.

26 For the biography of Bandinelli, sce Vasari, Lives, 11, 304.

27 Cellini, Autobiography, 340.

28 The English translation of this letter is taken from Robert Klein and Henri Zerner, Italian Art 1500-1600, Sources and Documents (Evanston, IL, 1989), 166. For the strife between Cellini and Bandinelli over the cathedral reliefs, sec Eugène Plon, Benvenuto Cellini, orfevre, médailleur, sculpreur: recherches sur sa vie, sur son oeuvre, et sur les pièces qui lui sont attribuées (Paris, 1883), 230-33.

29 For reproductions of more typical representations of the iconographic theme of Perseus Liberating Andromeda, confer Françoisc Siguret and Alain Laframboise, Andromède ou le héros à l'épreuve de la beauté (Paris, 1996), esp. colourplates II-VIII; and Parrick Le Chanu, Joachim Wtewael, Persée et Andromède (Paris, 1999), figs. 1, 3, 5, 7, 10, 13, 14 .

30 For sculpture in the round as more difficult to execute, see Sopra la differenza nata tra gli scultori e pittori, in Ferrero, Opere, 824-25. For Cellini as promoter of bronze casting compared to Vasari and for the downplaying of the craft of goldsmith in the $1568 \mathrm{cdi}$ tion of Vasari's Vite, see Marco Collareta, "Benvenuto Cellini ed il destino dell'oreficeria," in Nova and Schreurs, Benvenuto Cellini, 161-200.

31 Ferrero, Opere, 812. "[E]ssendo nato di rilicvo, io sono necessitato a inalzarlo più e lodarlo, per esserc cosa più mirabile di tutte l'altre."

32 Corinne Mandel, "Perseus and the Medici," Storia dell'Arte 87 (1996): 168-87.

33 For Cellini's Della Architettura, confer Ferrero, Opere, 813-21. The tiny edifice on the Saltcellar is commented briefly in Michacl Cole, Principles of Sculpture, 26. See page 134 of the same volume for Andromeda's pediment as "artificed." Architcctural models for the temple on Cellini's Medal for Clement VII are discussed in Bcth L. Holman, "'For Honor and Profit': Benvenuto Cellini's Medal of Clement VII and His Comperition with Ciovanni Bernardi," Renaissance Quarterly 58 (2005): 512-75.

34 The texts accompanying Cellini's proposals for the Accademia seal are transcribed in Charles Avery and Susanna Barbaglia, L'Opera completa del Cellini (Milan, 1981), 99-100.

35 Ferrero, Opere, 813-14.

36 Ferrero, Opere, 813. "L'architettura si è arte all'uomo di grandissima necessità, sì come sua vesta e armadura, e ancorea per ibci suoi ornamenti la diviene cosa mirabile...." 
37 Ferrero, Opere, 820-21.

38 Stephan Morét comments on the theoretical character of the base, but does nor consider the rclicf in his discussion of viewpoints, "Der paragone im Spiegel der Plastik," in Nova and Schreurs, Benvenuto Cellini, 19-36. In his P'erseus und Medusa (Stuttgart 1961), Wolfgang Braunfels notes the frontality of the Perseus on its base viewed from the piazza, which he relates to the Donatello revival of the 1540s and 1550s, but not to the paragone debate.

39) Avery and Barbaglia, L'Opera completa del Cellini, 95.

10) Morét signals this progression in Cellini's writings and discusses the influence of his vedute on other sculptors in "Der paragone im Spiegel der Plascik," in Nova and Schreurs, Benvenuto Cellini, 19-36.

41 "Fr[atr] is ut arma/geras nudus ad/astra volo"

42 For photographs of the wax model, see Popc-Hennessy, Cellini, plates 87 and 88 .

4.3 On the restoration, see Cristina Acidini Luchinat, "Il recente restauro del Perseo," in Nova and Schreurs, Benvenuto Cellini, 171-79; and Lorenzo Morigi, "Cellini's Splendor. The Reversible Theory of Restoration," Sculpture Review 48, 3 (Fall 1999): 14-19. Photographs of the statue taken while it was indoors are reproduced in Antonio Paolucci, Cellini (Florence, 2000), 28-33.

44 Cellini, Autobiography, 366.

45 "I discovered that the Duke and Duchess wcre out riding, and as the base was already prepared I had the little statues brought down and straight away soldered them in, each onc in its right placc." Cellini, Autobiography, 367.

46. For the moving of Judith and Holofernes, see Adrian W. B. Randolph, Engaging Symbols (Ncw Haven and London, 2002), 242-85. For the Piazza della Signoria as the "prime arena" of the school of Florence, see Charles Davis, "Benvenuto Cellini and the Scuola Fiorcntina," North Carolina Museum of Art Bulletin 13, 4 (1976): 41

47 Further discussion of Cellini's "humanism" is found in Gwendolyn Trottein, "l.e problème de l'orncment chez. Cellini: théoric, iconographie et humanisme," RACAR (Revue d'art canadienne/Canadian Art Review) XXVII, 1-2 (2000), 40-43.

48 Leon Battista Albcrti, On Painting, trans. Cecil Grayson, introduction and notes Martin Kemp, Harmondsworth, Middlesex, UK, 1991,61

19) Gender politics on the Piazza della Signoria are discussed in Yael Fven, "The Loggia dei Lanzi: A Showcase of Female Subjugation," in The Expanding Discourse: Feminism and Art History, eds. Norma Broude and Mary D. Garrard (New York, 1992), 127-38; Cieraldine A. Johnson, "Idol or Idcal? The Power and Potency of Ficmale Public Sculpture," in Picturing Women in Renaissance and Baroque Italy, eds. Geraldine A. Johnson and Sara F. Matthews Gricco (Cambridge, UK, 1997), 222-45; and Randolph, Engaging Symbols, 242-85. For Cellini's gendering of the arts, see Gwendolyn Trottein, "Le problème de l'ornement chez Ceellini," 39-40.
50 See, for examplc, Erwin Panofsky, Idea. A Concept in Art Theory, trans. Joseph J.S. Peake, 2nd ed. (Columbia, 1968), esp. 94-95; and Anthony Blunt, Artistic Theory in Italy. 1450-1600 (Oxford, UK, 1962), 54-56.

51 Vasari, Lives, 886.

52 For Michelangelo's funeral, see Rudolf Wittkower, The Divine Michelangelo: The Florentine Academy's Homage on his Death in 1564, a facsimile edition of Esequie del Divino Michelangelo Buonarroti, Florence 1564 (Greenwich, Cl; 1964).

53 On the Perseus and Andromeda theme as an allegory of art in the sixteenth century, consult Siguret and Laframboise, Andromède ou le l'héros à l'épreuve de la beauté, 29-107.

54 For the water in which Artemis-L)iana stands, sce Peter Meller, "Geroglifici e ornamenti 'parlanti' nell'opera del C.cllini," Arte Lombarda 3/4 (1994): 9-16.

55 For Diana-Artemis as goddess of the moon and the tides, see Jean Sczncc, The Survival of the Pagan (iods (New York, 1953), 46.

56 According to Cole, the small, flying Perseus's gaze is directed at Andromeda, but it is worth noting that what the hero in the relief sces is very similar to what the large, free-standing Perseus sees underneath him, namely a reflectivc surface and a faceless female form. See Colc, Cellini and the Principles of Sculpture, 130 and 137.

57 Philippe Morel, "I.a Chair d'Andromède et le Sang de Méduse. Mythologie et rhétorique dans lc P'ersée et Androméde de Vasari," in Siguret and Laframboise, Andromède ou le héros à l'épreuve de la beauté, 57-83.

58 Gerhard Wolf, "Der Splitter im Auge: 'Cellini' zwischen Narziß und Medusa," in Nova and Schreurs, Benvenuto Cellini, 315-36.

59 The squaring off and flatcening of Medusa's body was most apparent when it was possible to mount the scaffolding and gaze down upon the large bronzes during their recent restoration. However onc cxcellent photograph for viewing Medusa's body folded around Minerva's shield exists, that taken by David Finn and reproduced with his kind permission in fig. 9 .

60 Pope-Hennessy, Cellini, 183.

61 For Cellini's praise of Bronzino, sec Pope-Henncssy, Cellini, 183; and Cellini, Autobiography, 378.

62 Ferrero, Opere, 825.

63 "... una pittura vivc molti pochi anni, e quella di scultura è quasi eterna," Sopra la differenza, in Ferrero, Opere, 824.

64 For this variable star, which is now known to be three stars, see Stephen R. Wilk, Medusa: solving the mystery of the gorgon (Oxford, UK, 2000), 107-28.

65 Cellini insists in Sopra la differenza that man made by God is "di rielievo tutto tondo." See Ferrero, Opere, 822.

66 For Cellini's imitation of Michelangelo in the construction of his autobiography, scc the chapter entitled "Benvenuto Buonarroti," in Paul Barolsky, Michelangelo's Nose. A Myth and its Maker (University Park, PA, and London, 1990), 141-44.

67 Cellini, Autobiography, 298-300. 
68 For Cellini's Jupiter as an "automaton," see Horst Brcdekamp, The Lure of Antiquity and the Cult of the Machine, trans. Allison Brown (Princeton, NJ, 1995), 1-2.

69 "La pittura non vuol dir altro che bugia ...." See Cellini's discourse entitled "Sopra la differenza nata tra gli scultori e pittori circa il luogo destro stato dato alla pittura nelle essequie del gran Michelagnolo Buonarroti," in Ferrcro, Opere, 823.

70 The curse of Fortune and the stars in the Vita is treated in Gwendolyn Trottein, "Battling Fortune in Sixteenth-Century Italy: Cellini and the Changing Faces of Fortuna," in Artful Armies, Beautiful Battles. Art and Warfare in Early Modern Europe, ed. Pia C.uneo (Leiden, Boston, and Cologne, 2002), 213-34.

71 Cellini, Autobiography, 394.

72 For the allegory of Virtue and Fortune on the ceiling in Vasari's home in Arezzo, scc Liana Cheney, The Paintings of the Casa Vasari (New York and London, 1985), 166-70; and more recently her The Homes of Giorgio Vasari (New York, 2006), 140-44. See also Rudolf Wittkower, Allegory and the Migration of Symbols (Boulder, CO, 1977), 105-()6.

73 Vasari, Lives, 267.

74 "... perche il discgno $\mathrm{c}$ di due sorte, il primo e quello che si fa nell'Imaginativa e il sccondo tratto da quello si dimostra con linee, e questo ha fatto l'huomo tanto ardito che egli si c messo a ghareggiare con questo gran padre Apollo ...." For the complete text of this seal, see Avery and Barbaglia, Opera Completa, 100. For Cellini's treatise on the art of drawing, see Patricia I.. Reilly, "Drawing the Line. Benvenuto Ccllini's On the Principles and Method of Learning the Art of Drawing and the Question of Amateur Drawing Education," in Margarec A. Gallucci and Paolo L. Rossi, Benvenuto Cellini: Sculptor, Goldsmith, Writer (Cambridge, UK, 2()()4), 26-50.

75 On the contest betwecn Lconardo and Michelangelo, see Goffen, Renaissance Rivals, 143-44.

76 Reactions to the picce, especially in the poetry of the period, are discussed in Shcarman, Only Connect, 55-57.

77 Cellini, Autobiography, 117.

78 Cole, Cellini and the Principles of Sculpture, 134.

79 The quintessential image for canine envy is that of two dogs fighting over a bone. On the concept of envy among artists, sec David Cast, The Calumny of Apelles. A Study in the Humanist Tradition (New Haven and I ondon, 1981), 138-55

80 "E quelli uomini che hanno altre volte scritto in lode della pittura, talvolta si sono dimenticati di non essere loro stessi di scultura; e come uomini dipinto, e non di rilievo, hanno parlato." Ferrero, Opere, 812.

81 For Cellini's persona in the Vita as imitative of Michelangelo's furore and terribilità, see "Benvenuto Buonarroti," in Paul Barolsky, Michelangelo's Nose. A Myth and its Maker, 141-44.

82 See note 28 abovc.

83 Curiously, the chapter devoted to the artistic rivalry between Ban- dinelli and Cellini in Goffen's Renaissance Rivals also has the effect of devaluing both men's accomplishments. See note 20 above.

84 For Vasari's portraits of Cellini and Bandinelli, see W. Chandler Kirwin, "Vasari's 'Tondo of 'Cosimo I with his Architects, Engineers, and Sculptors' in the Palazzo Vecchio. Typology and Reidentification of Portraits," Mitteilungen des Kunsthistorischen Instituts in Florenz 15 (1971): 105-22.

85 For an interesting enumeration of the relief's shortcomings, see the description in A. Venturi, Storia dell'arte italiana, I a Scultura del cinquecento, part II (Nedeln, Liechtenstein, 1967), X, 479-31.

86 Michelangelo was replying to Benedetto Varchi's inquiry of 1546. For the English translation of his letter, see Robert Klcin and Henri Zerner, Italian Art 1500-1600. Sources and Documents (Evanston, IL, 1966), 14.

87 For the Perseus as a paragon of male beaury, sce "Ihe Mask of Mercury," the final chapter of my forthcoming volumc on Cellini's sculpture and prosc (Paris: Éditions du Regard, 2011).

88 Cellini's code of masculine honour is discussed in Margaret A. Gallucci, Benvenuto Cellini: Sexuality, Masculinity, and Artistic Identity in Renaissance Italy (New York, 2003), 108-41. For his pursuit of honour and profit through art, see Beth I. Holman, "'For Honor and Profit': Benvenuto Cellini's Medal of Clement VII and His Competition with Giovanni Bernardi," 512-75. For art as revengc, scc (iwcndolyn Trottein, "Benvenuto Cellini: simbologia e autobiografia," Il pensiero simbolico nella prima eta moderna, eds. Annarita Angclini and Pierre Caye (Florence, 20(07), 173-95. 